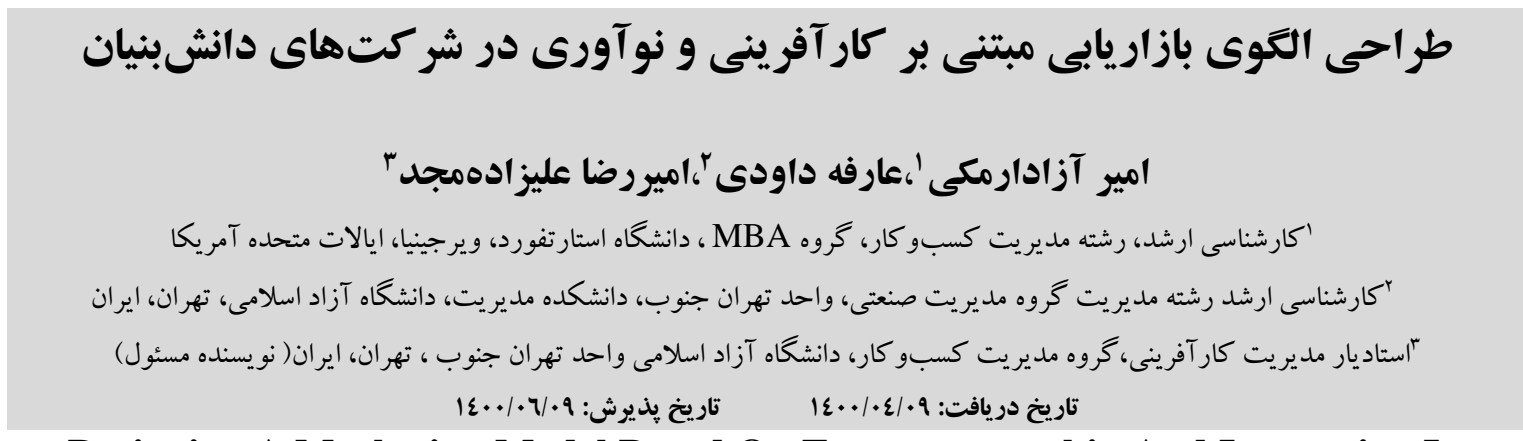

\title{
Designing A Marketing Model Based On Entrepreneurship And Innovation In Knowledge-Based Companies
}

\begin{abstract}
Marketing is one of the most important pillars of any business, but marketing in other conventional ways does not respond to the turbulent business environment that is associated with risk and uncertainty. The salient nature of marketing and entrepreneurship is the search for opportunities to turn them into practical and marketable ideas. By evaluating the existing models in this field, there was a lack of a model for knowledgebased companies. The present study is applied in terms of purpose and qualitatively in terms of method. First, qualitative data were collected through content analysis and semi-structured interviews, then the indicators were screened by experts. Then, the extracted indicators in order to create the model were grouped by experts and in the focus group meeting. Each of the related components and concepts were analyzed and mapped separately by Max Koda software. Finally, the model of this research was designed based on entrepreneurshipbased marketing and innovation into four dimensions: contextual marketing, entrepreneurial networks, internal guiding core, and innovative entrepreneurship, each of which has several components.
\end{abstract}

Amir Azadarmaki ${ }^{1}$, Arefeh Davoodi ${ }^{2}$, Amirreza Alizadehmajd $^{3}$

${ }^{1}$ Masters Degree in Business Administration, MBA, University of Stratford, Virginia, USA

${ }^{2}$ Master of Management, Department of Industrial Management, South Tehran Branch, Faculty of Management, Islamic Azad University, Tehran, Iran

${ }^{3}$ Assistant Professor of Entrepreneurship Management, Department of Business Management, Islamic Azad University, South Tehran Branch, Tehran, Iran (Corresponding Author) Accepted: (29/08/2021)

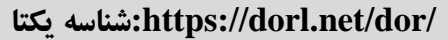

\section{Abstract}

Keywords

Marketing, Entrepreneurship, Entrepreneurial Marketing, Innovation, Knowledge-Based Companies.

$$
\begin{aligned}
& \text { بازاريابى از مهمترين اركان هر كسبوكارى است اما بازاريابى به }
\end{aligned}
$$

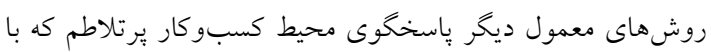

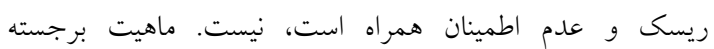

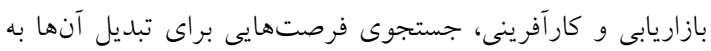

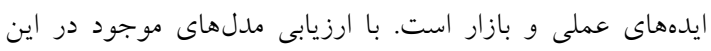

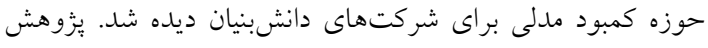

$$
\begin{aligned}
& \text { حاضر ازلحاظ هدف كاربردى و ازلحاظ روش كيفى مىباشد ابتدا } \\
& \text { دادههاى كيفى از طريق تحليل مضمون و مصاحبههاى نيمه }
\end{aligned}
$$

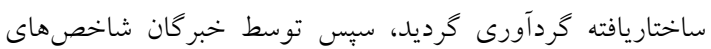

$$
\begin{aligned}
& \text { غربال شدند. در ادامه شاخصهاى مستخرج در راستاى خلق مدل، }
\end{aligned}
$$

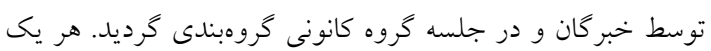

$$
\begin{aligned}
& \text { از مؤلفهها و مفاهيم مرتبط جداگانه توسط نرمافزار ماكس كودا } \\
& \text { تحليل و ترسيم شده است. درنهايت مدل اين يزوهش بر بر اساس }
\end{aligned}
$$

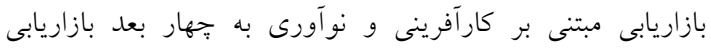

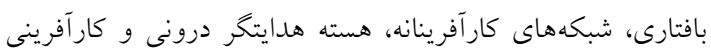

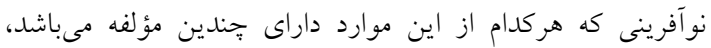

$$
\begin{aligned}
& \text { طراحى كرديد. } \\
& \text { وازمهاى كليدى } \\
& \text { بازاريابى، كار آفرينى، بازاريابى كار آفرينانه، نوآورى، شركتهاى } \\
& \text { دانشبنيان }
\end{aligned}
$$




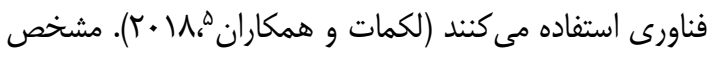

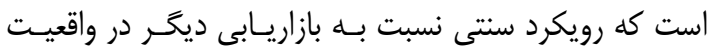

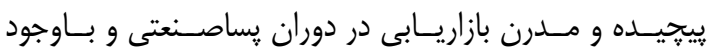
ييشرفتهاى تكنولوزيك در زمينه ارتباطات و وسـايل ارتبـاط

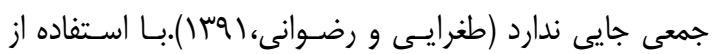

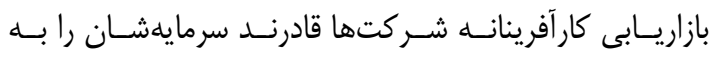

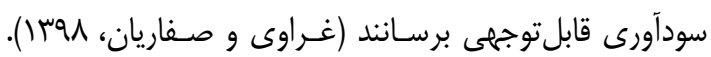

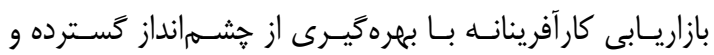

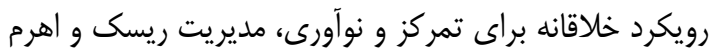

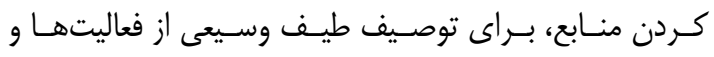
واكنشها به كار مىرود. (يانگ

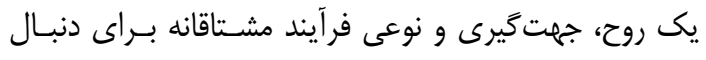

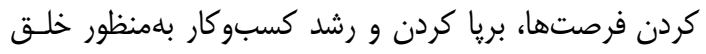

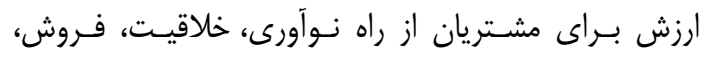

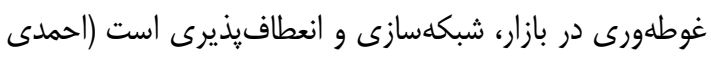

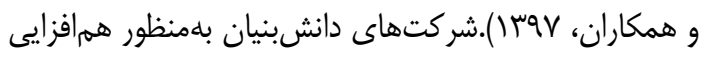

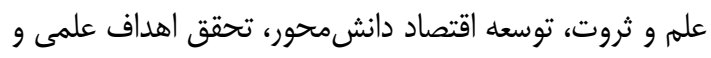

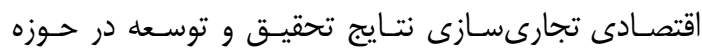

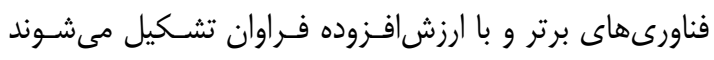

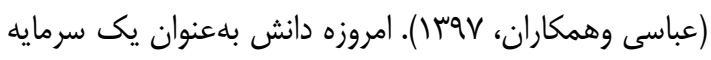

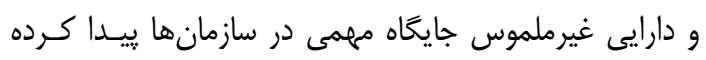

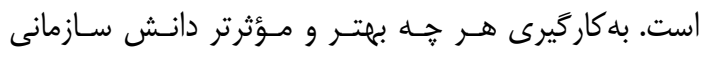

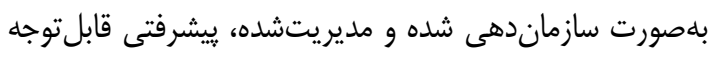

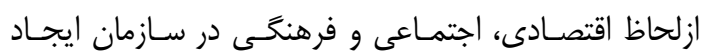

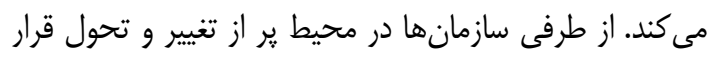

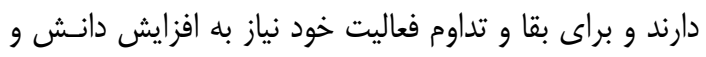

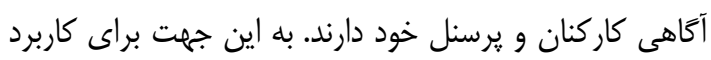

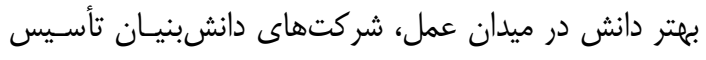

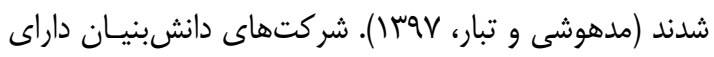

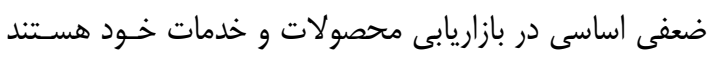

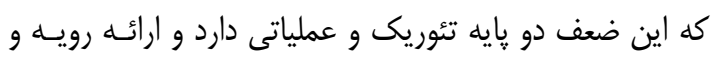

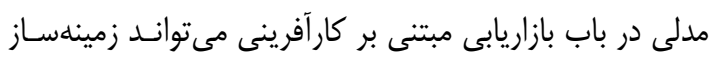

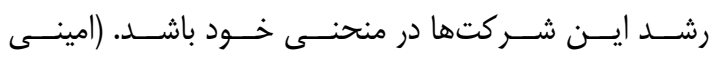

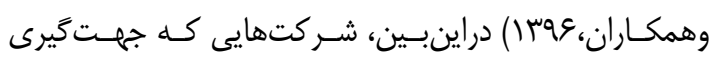

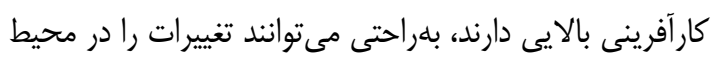

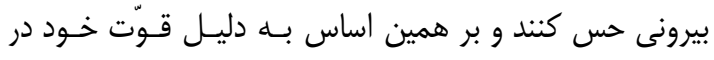

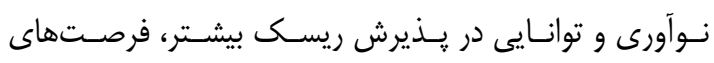

\footnotetext{
${ }^{5}$ Lekmat\&etal
}

${ }^{6}$ Yang

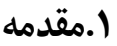

سابقه بازاريابى از تاريخ كار آفرينى جــا نيســ، امـا محققــان

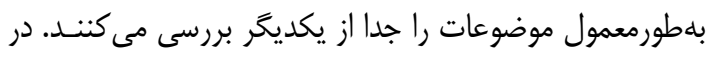

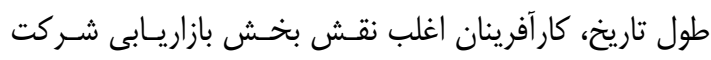

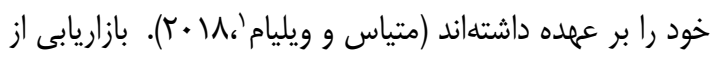

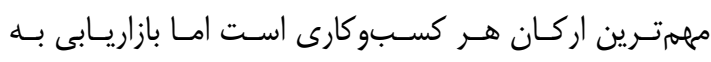

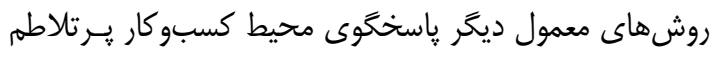

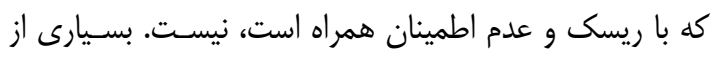

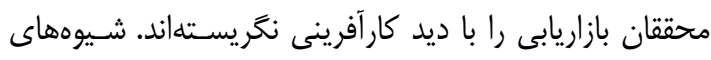

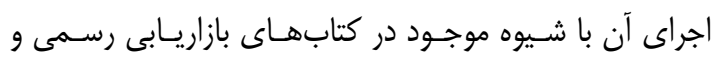

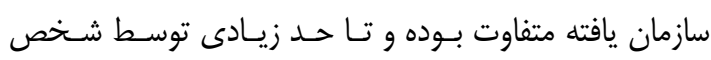

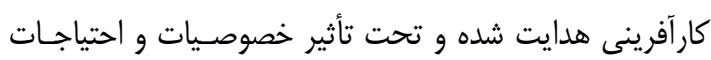

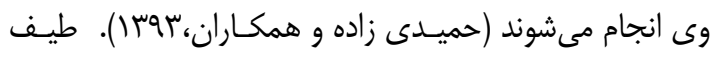

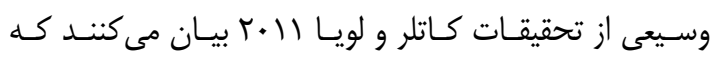

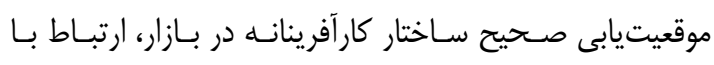

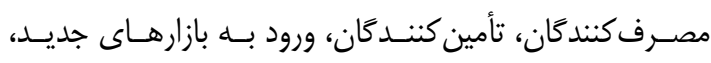

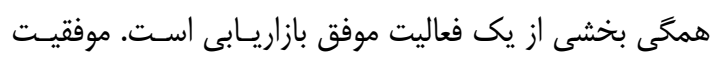

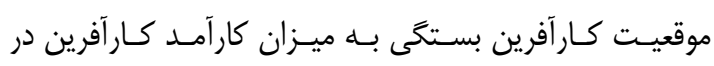

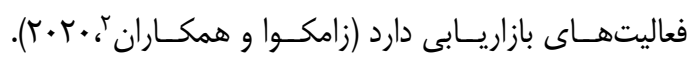

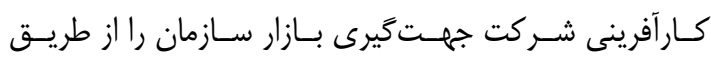

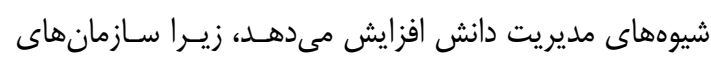

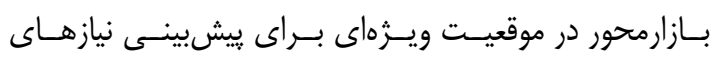

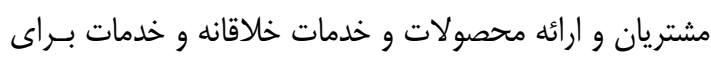

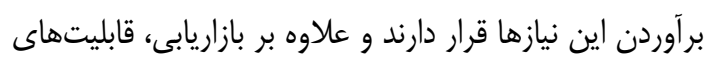

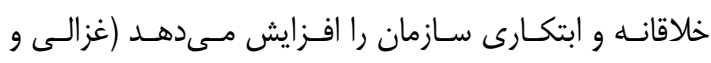

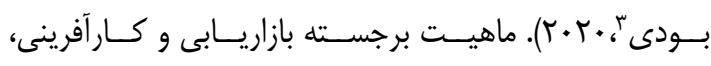

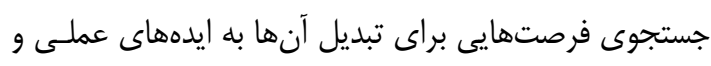

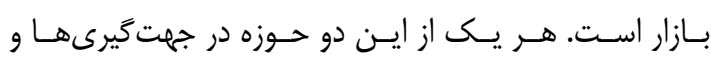

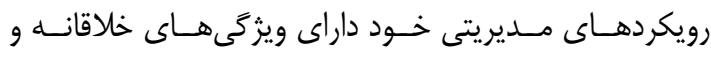

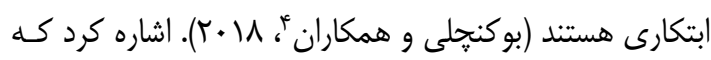

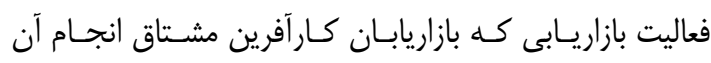

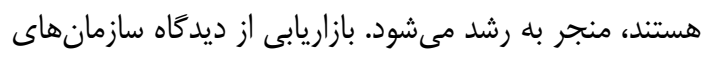

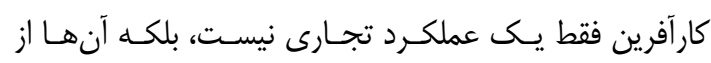

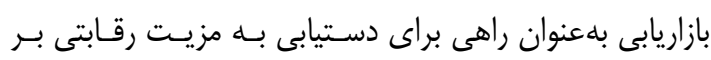

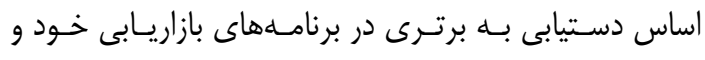

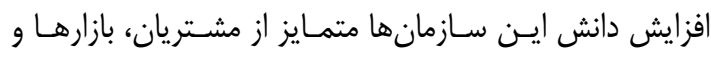

\footnotetext{
${ }^{1}$ Mathias\&Williams

${ }^{2}$ Zamkova\&etal

${ }^{3}$ Ghezali\&Boudi

${ }^{4}$ Bocconcelli\&etal
} 
(ملكى و همكاران،بوسا)؛ اما كارآفرينى در بازاريابى به واكنش مناسب، باسخكويى و داشتن روحيه فرصتطانلبانه اشاره مى كند و مباحثى نظير نوآورى كرايى و ارتباط با مشترى

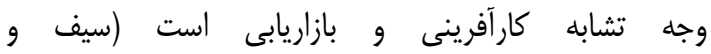

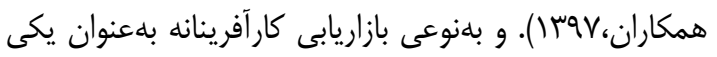
از علوم ميانرشتهاى، فصل مشتركى از بازاريابى و كار كار آفرينى

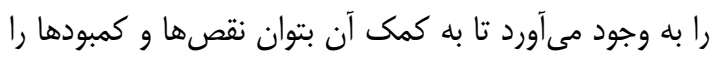

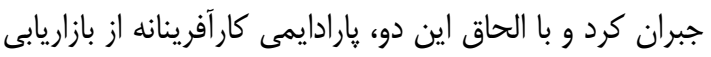

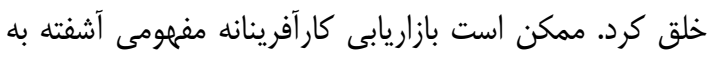

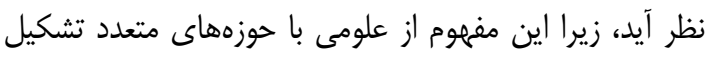

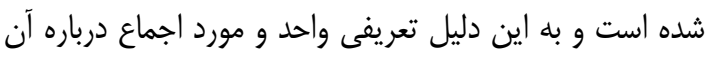

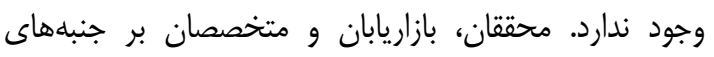

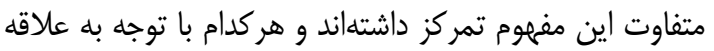

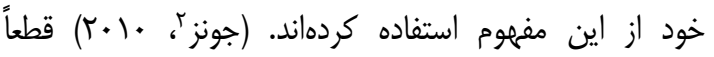

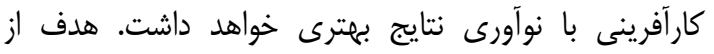

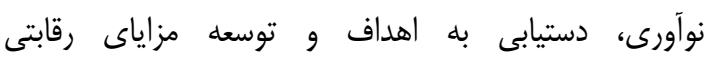
مورداستفاده سازمان است. اين مزايا مىتوانند از توانايىهاى تئي

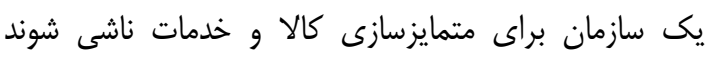

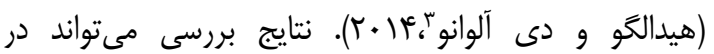

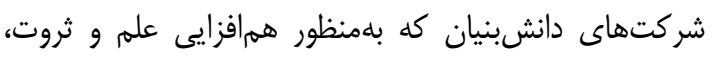

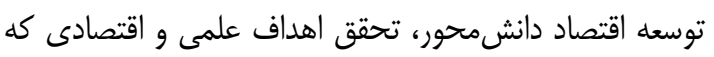

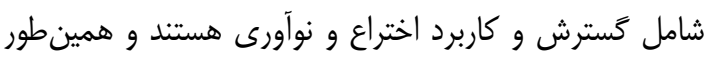

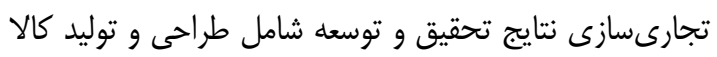

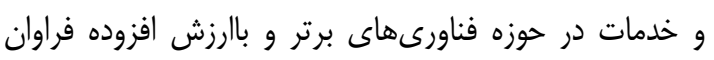

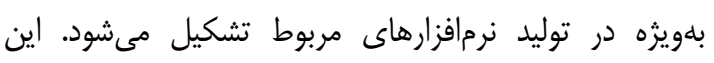

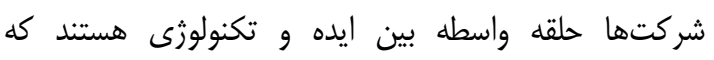

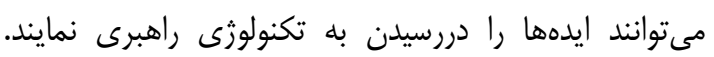

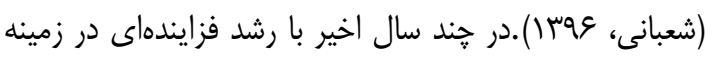

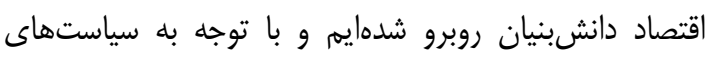

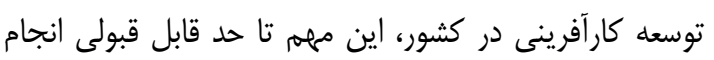

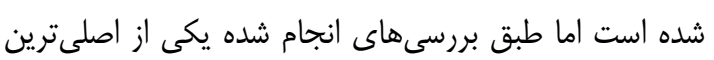

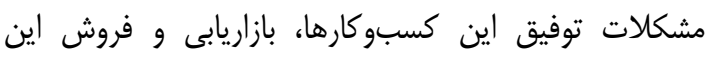

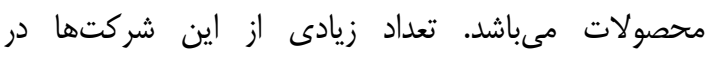

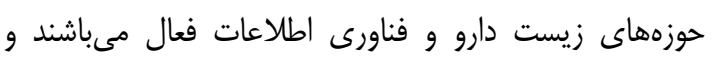
سبقه تحصيلى تجربى بنيان كذاران اين كسبوكار ارها

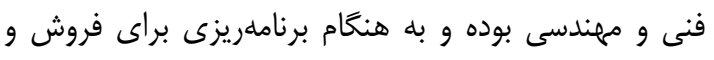

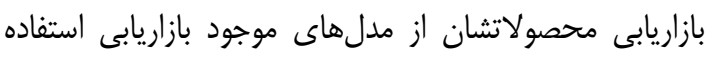

\section{Jones}

${ }^{3}$ Hidalgo \& D'Alvano

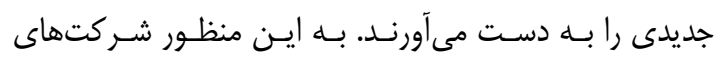

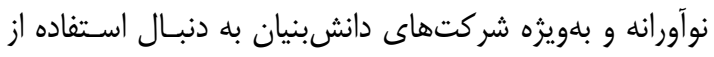

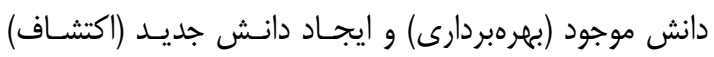
هستند (ساهى و همكاران'، (ب) إن).

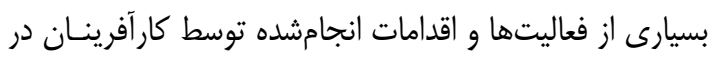

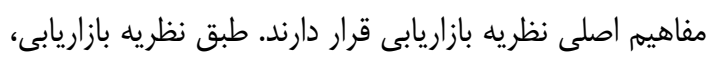

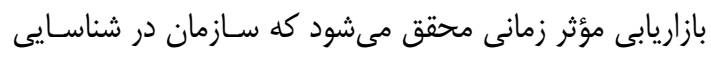

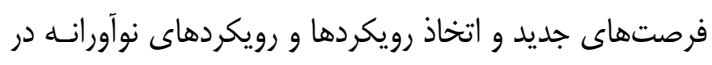

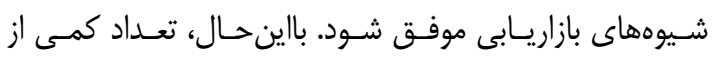

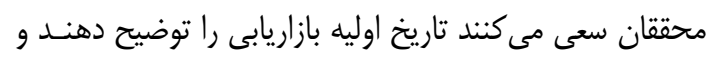

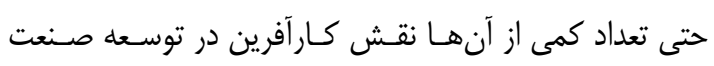

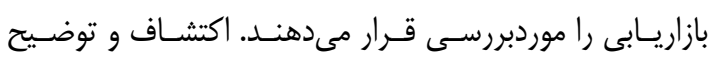

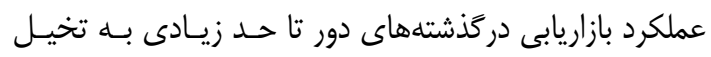

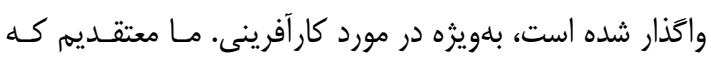

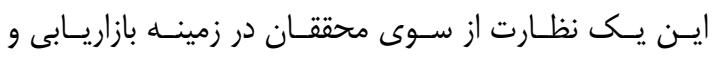

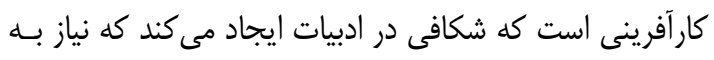

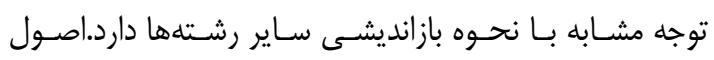

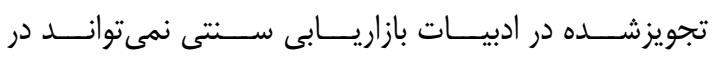

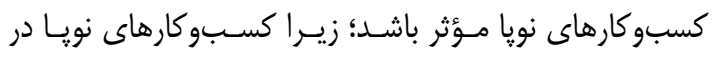

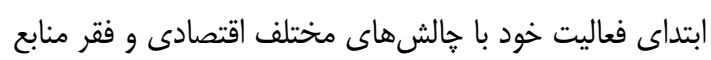

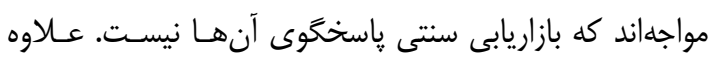

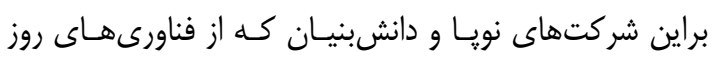

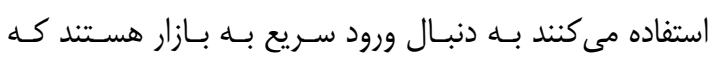

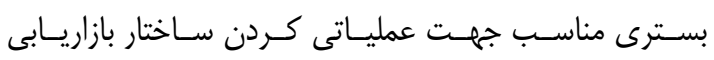

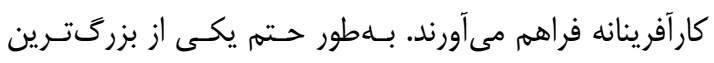

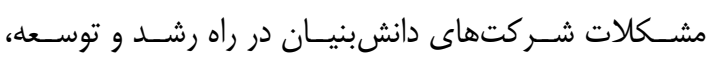

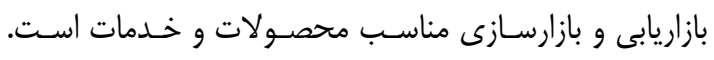

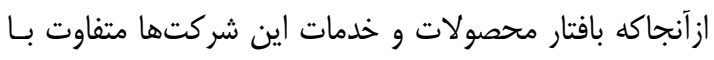

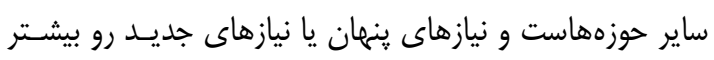

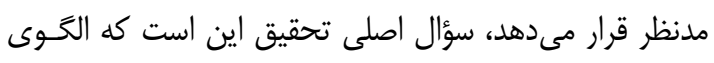

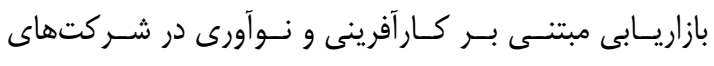
دانشبنيان جيست؟

\section{ז.مرورى بر مبانى نظرى و ييشينه يزوهش}

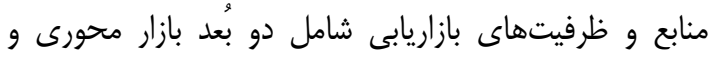

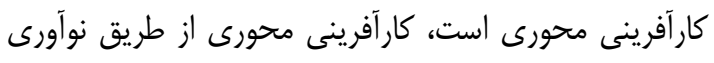

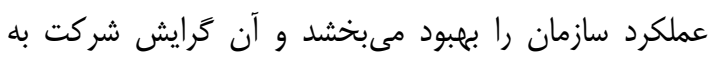

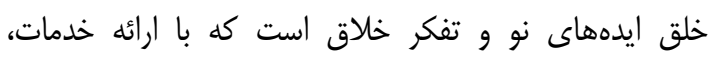

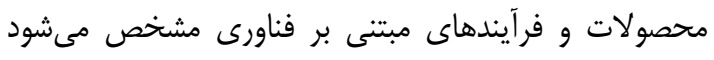

\footnotetext{
${ }^{1}$ Sahi\&etal
} 


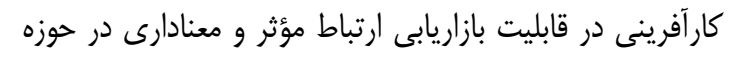

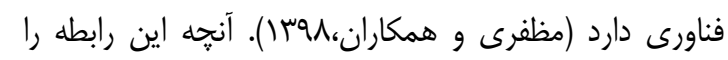

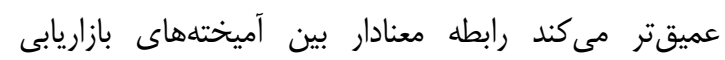

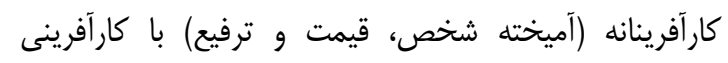

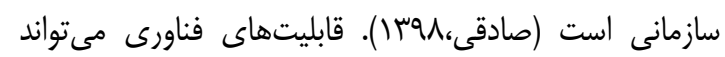

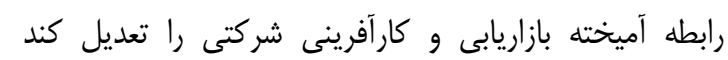

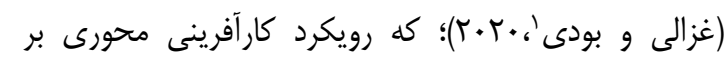

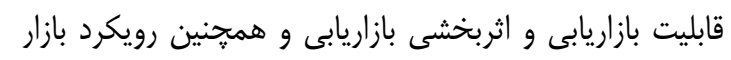

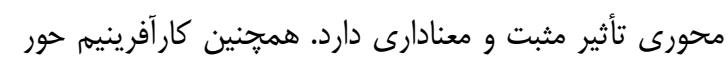

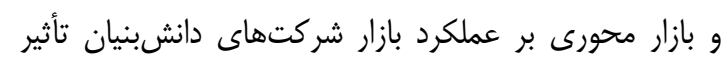

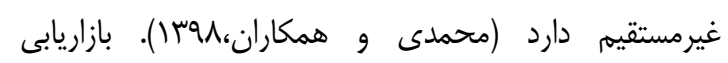

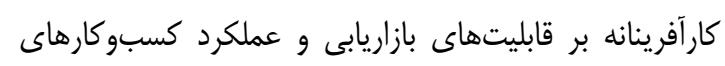

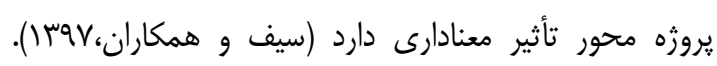

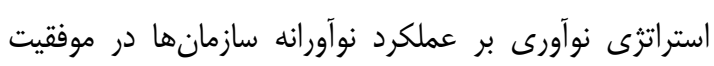

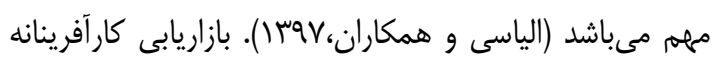

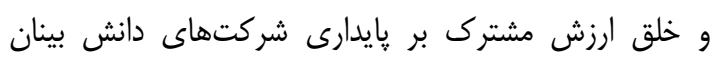

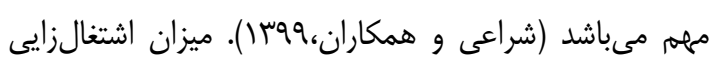

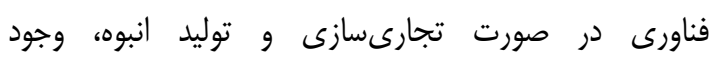

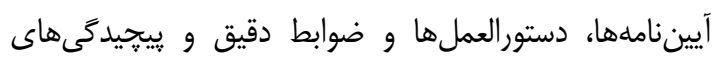

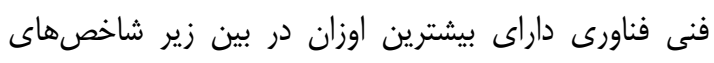

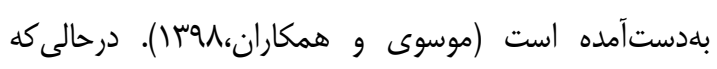

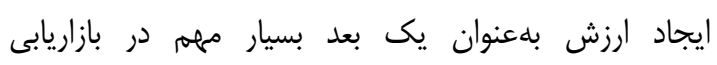

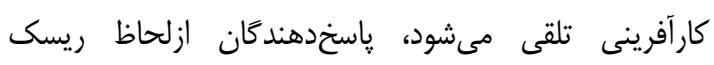

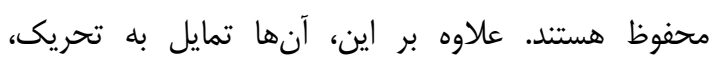

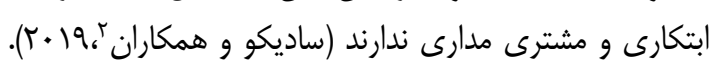

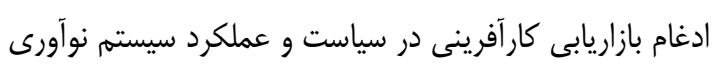

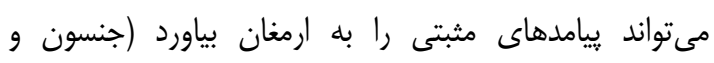

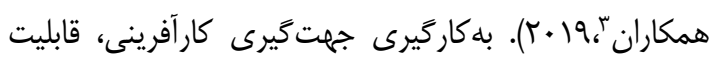

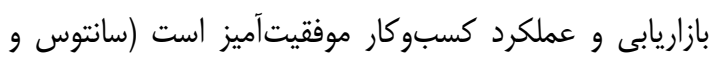

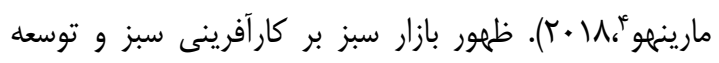

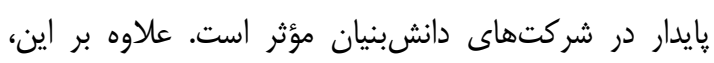

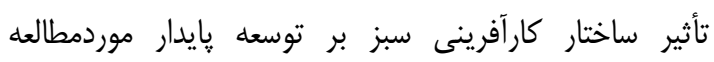

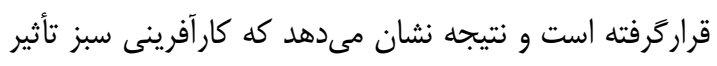

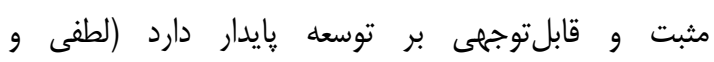
همكارانه،م( +r). اثر تعديل كننده ساختار شبكه (اندازه، تنوع و

\footnotetext{
${ }^{1}$ Ghezali\&Boudi

${ }^{2}$ Sadiku\&etal

${ }^{3}$ Jenson\&etal

${ }^{4}$ Santos\& Marinho

${ }^{5}$ Lotfi\&etal
}

مىنمايند، اما اصلىترين شكاف اينجاست كه مدلهاى مرسوم

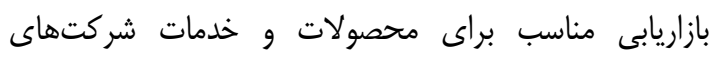

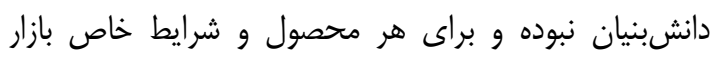

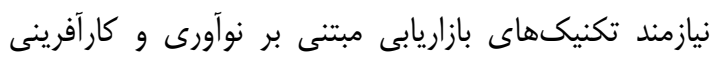

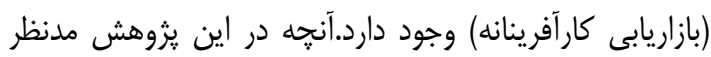

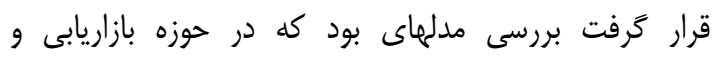

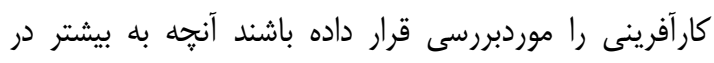

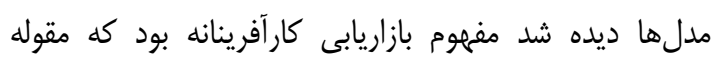

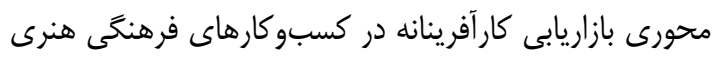

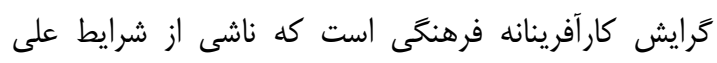

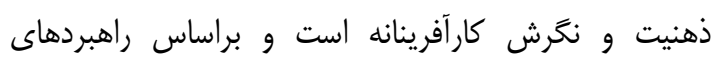

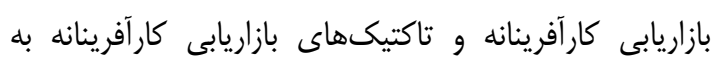

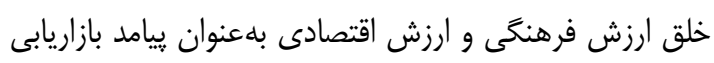

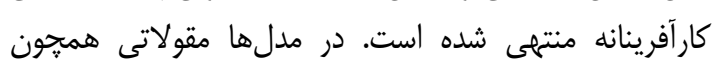

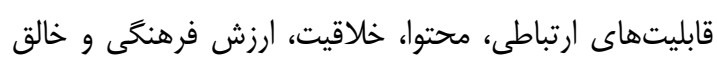

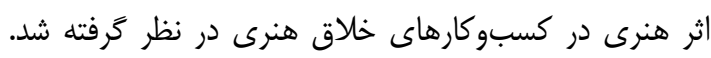

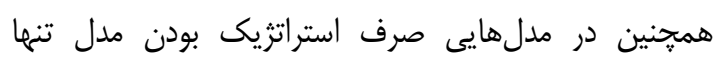

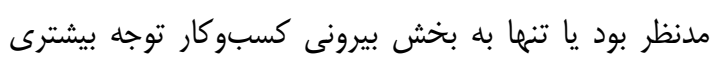

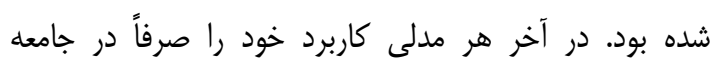

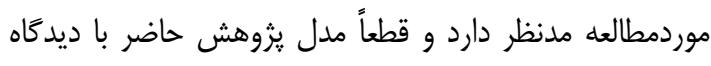

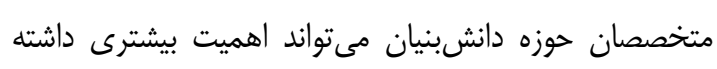

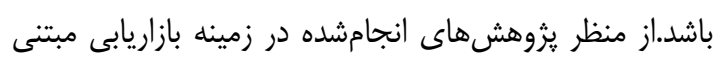

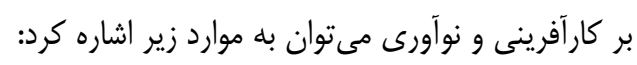

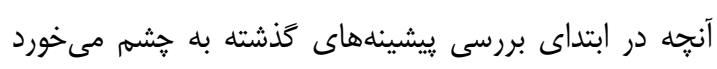

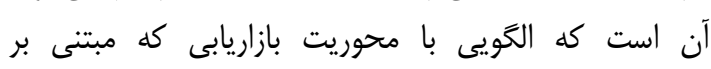

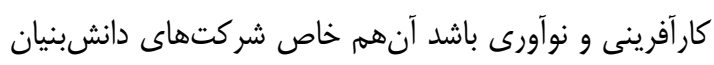

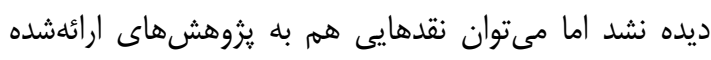

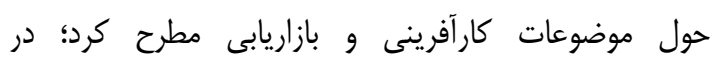

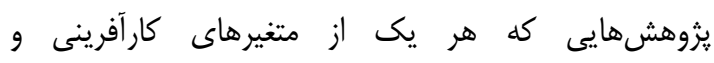

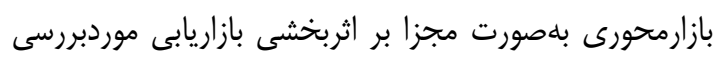

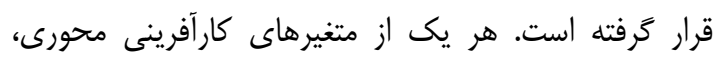

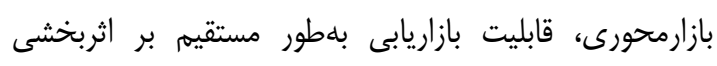

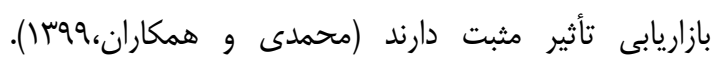

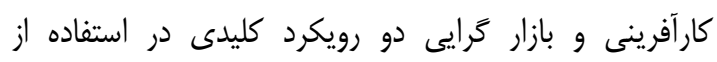

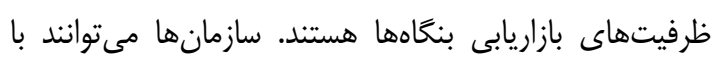

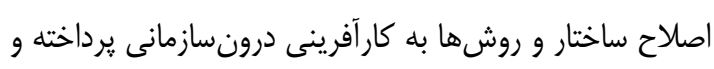

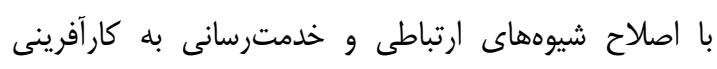

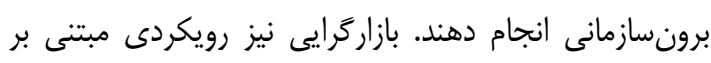

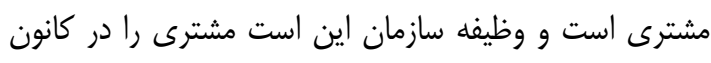

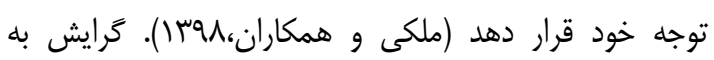




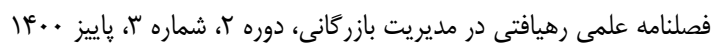

\begin{tabular}{|c|c|c|c|c|c|}
\hline 10 & $\Delta$ & $r$ & $r$ & $\Delta$ & مرحله مصاحبه \\
\hline$\Delta$ & 1 & $r$ & 1 & $r$ & كرحله گرَوه \\
\hline
\end{tabular}

بلهورمعمول، نمونهَيرى در يزوهشهاى كيفى از نوع غير

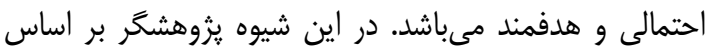
آكاهى و آشنايى با جامعل، دست به انتخاب هدابل هدفمند نمونه

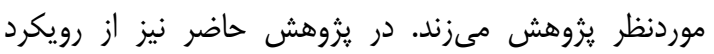

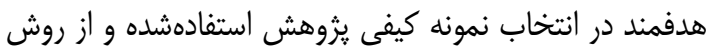

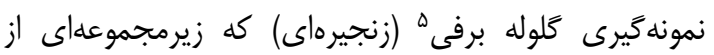

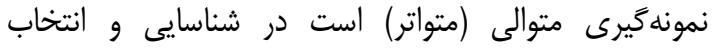

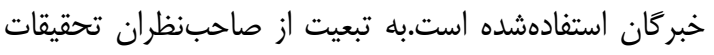

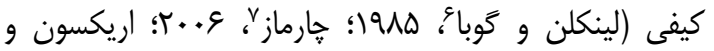

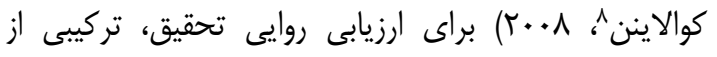

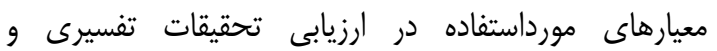

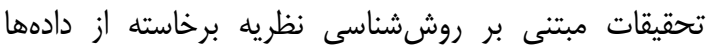

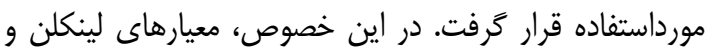

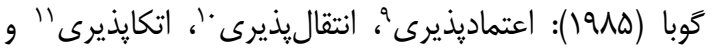
تصديق يذيرى" برابر جدول شماره زير بررسى كرديد. جدول ا. ارزيابى روايى تحقيق شرح معيار

بررسى حندينباره سؤال هاى مصاحبه نيمه ساختار يافته

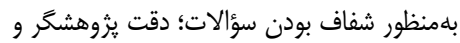
جندين بار برارى كدهاى اتخاذشده از مصاحبهاء

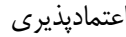

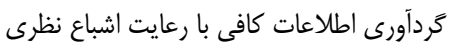

نمونهَّيرى نظرى؛ مفاهيم نظرى اراده شده از

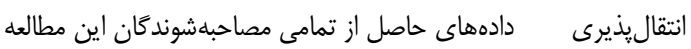

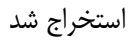

\footnotetext{
${ }^{5}$ Snowball Sampling

${ }^{6}$. Lincoln \& Guba

7. Charmaz

8 . Eriksson \& Kovalainen

१. Credibility

'. Transferability

". Dependability

ir. Confirmability
}

قدرت)، متغيرهاى محيطى (تلاطهم بازار، آشفتخى فناورى، شدت رقابت، قدرت تأمين كننده و رشد بازاز ) و اندازه شركت

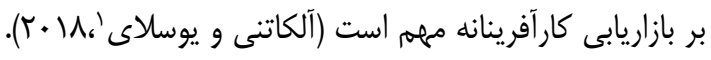

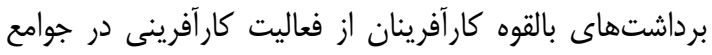

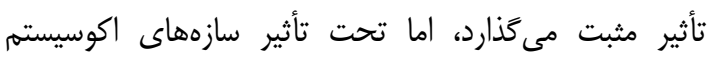

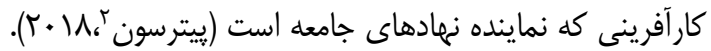

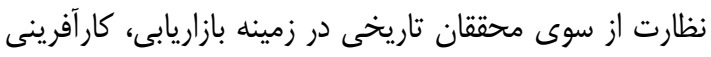

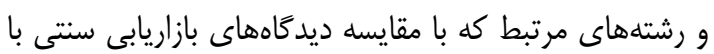
ديدكاههاى كارآفرينى و رابطهاى در دورانهاى مخاف مختلف،

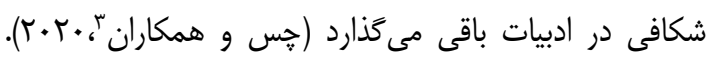
همجنين اهميت بررسى اين حوزه در شركتهاى دافي دانشبنيان

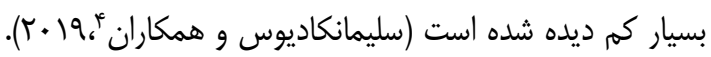
آنجه در تحقيقات مىتوان فهميد اين است كه قطع بهيقين

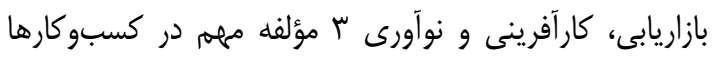

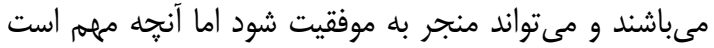

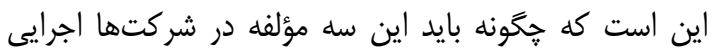
شوند موردى كه در خيلى از يزوهشها به به آن اشارهاى نشده و

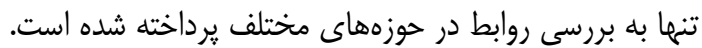

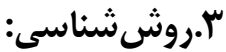

روش يزوهش حاضر از نوع كيفى است. بر اساس اهداف

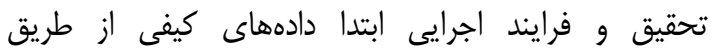
مصاحبههاى نيمه ساختاريافته و تحليل محتواى متون (مرور

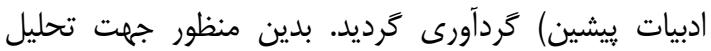

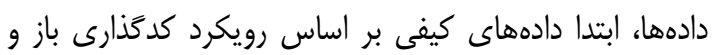
محورى به همراه برخى شواهد مستند ارائه مى كردد. در بإيان تحليل دادهاى كيفى مدل ييشنهادى تحقيق بر اساس

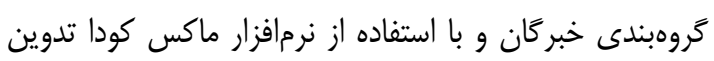
مى كردد.مشخصات كلى مصاحبهشوندانان در مرحله كيفى تحقيق در جدول زير اشاره شد.

جدول (. مشخصات كلى مصاحبهشوندكًان در مرحله كيفى تحقيق

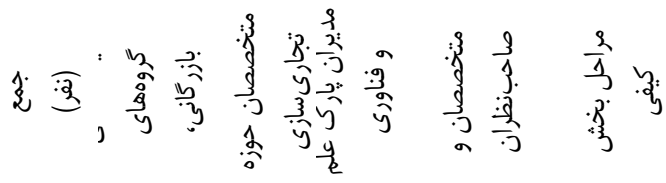

\footnotetext{
${ }^{1}$ Alqahtani\& Uslay

${ }^{2}$ Peterson

${ }^{3}$ Chase\&etal

${ }^{4}$ Suleimankadievs\&etal
} 
آزادارمكى ،داودى و عليز اده مجد:طراحى الكوى بازاريابى مبتنى بر كار آفرينى و نو آورى در شر كتهاى دانشبنيان

شركتهاى دانشبنيان كدام است؟

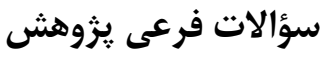

شاخصهاى الكَوى بازاريابى مبتنى برو كارآفرينى و نوآورى در

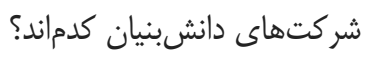

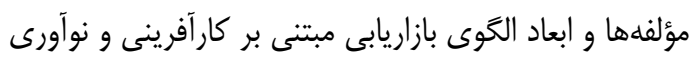
در شركتهاى دانشبنيان كدماند؟ بإن

يافتهها جهت ياسخ به سؤالات تحقيق از روش يزوهن كئ كيفى استفاده

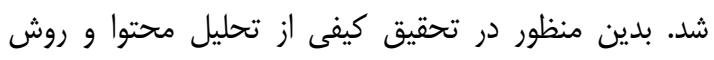

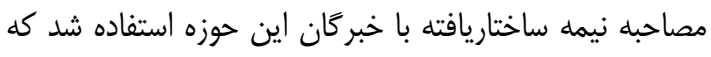

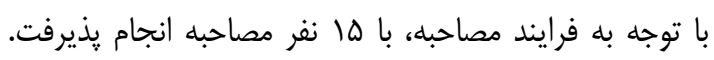

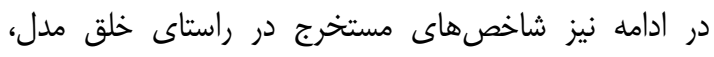

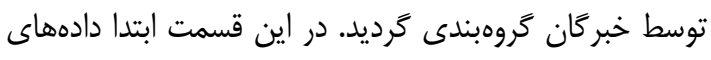

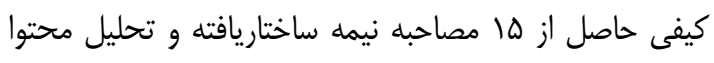

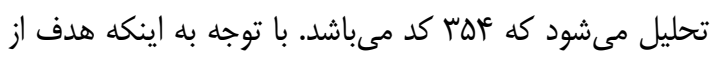

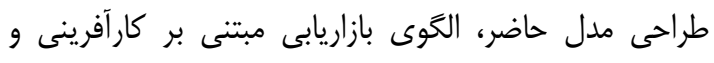

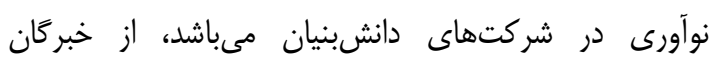

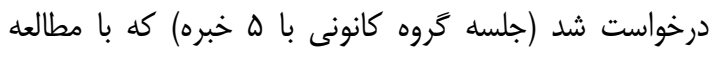

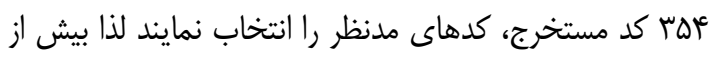

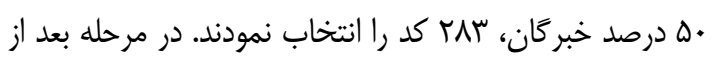

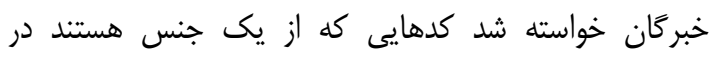

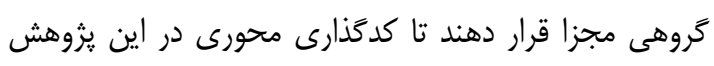

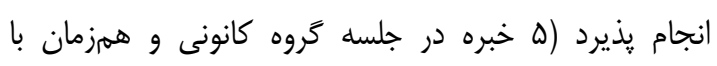

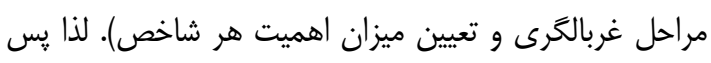

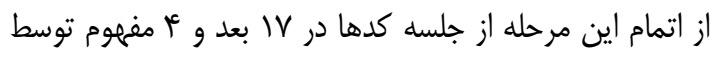

$$
\text { خبر كان گَروهبندى شد. }
$$

\begin{tabular}{|c|c|}
\hline موضوع تحقيق؛ رعايت ابزارهاى روشيات جارى ويشين خبركان در مورد & اتكايذيرى \\
\hline 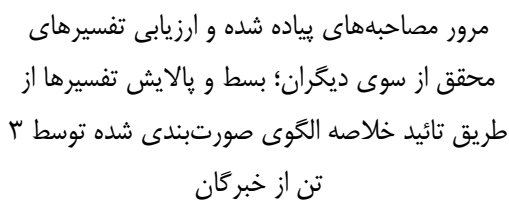 & تصديق يذيرى \\
\hline
\end{tabular}

براى محاسبه پايايى مصاحبهها نيز از روش بازئ بآزمون

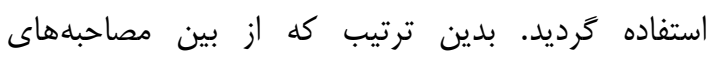

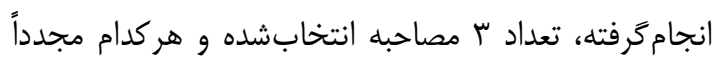

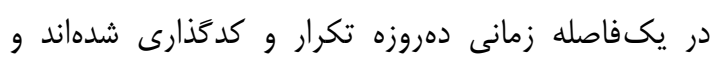

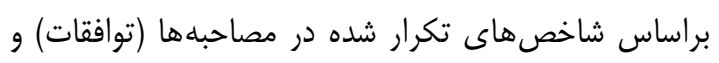

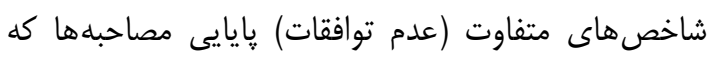
نتايج آن در جدول زير نشان دادهشده است.

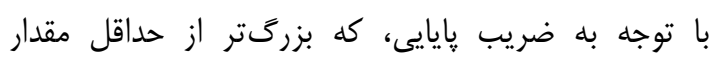

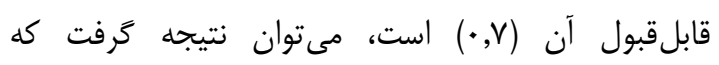

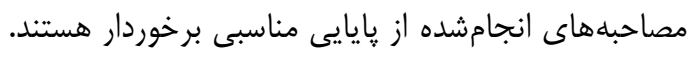
جدول r. محاسبه يايايى باز آزمون

\begin{tabular}{|c|c|c|c|c|c|}
\hline بازيآيآيى & تعداد & تعدافقات & كدهاد كل & مصاح & رديف \\
\hline • & $\Lambda$ & 19 & is & $\mathrm{A} 2$ & 1 \\
\hline$\cdot, \mathrm{rrq}^{\mathrm{q}}$ & $\pi$ & IV & 18 & A6 & $r$ \\
\hline$\cdot, \Delta K I$ & 1. & זr & $\Delta S$ & A15 & $r$ \\
\hline
\end{tabular}

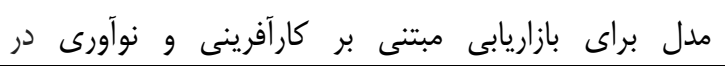

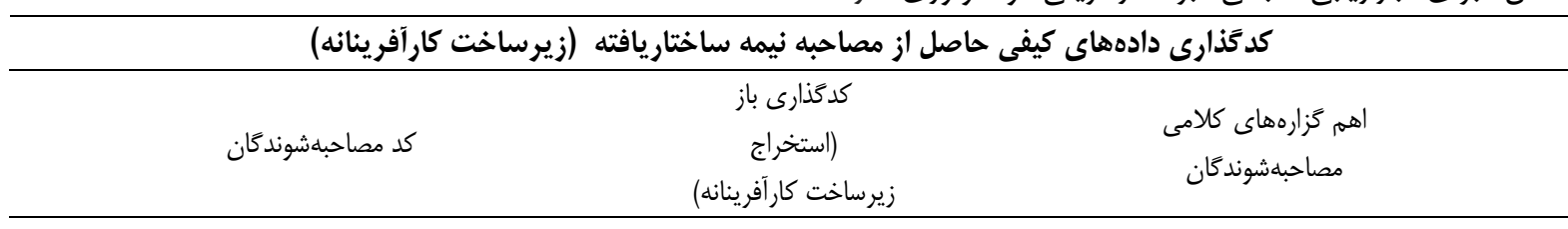

\begin{tabular}{|c|c|c|}
\hline & زيرساخت كار آفرينانه) & \\
\hline $\begin{array}{c}\mathrm{Z} 2, \mathrm{Z} 5, \mathrm{Z} 6, \mathrm{Z} 8, \mathrm{Z} 11, \mathrm{Z} 14, \mathrm{Z} 16, \mathrm{Z} 15 \\
\text { X1,X2,X3,X5,X6,X7 }\end{array}$ & فرصت هاى كارآفرينى & 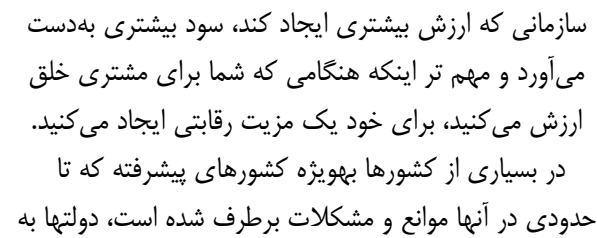 \\
\hline $\begin{array}{l}\mathrm{Z} 2, \mathrm{Z5}, \mathrm{Z7}, \mathrm{Z} 8, \mathrm{Z} 10, \mathrm{Z} 11, \mathrm{Z} 15, \mathrm{Z} 15 \\
\text { X1,X2,X3,X4,X5,X6,X7 }\end{array}$ & خودكار آمدى كار آفرينانه & 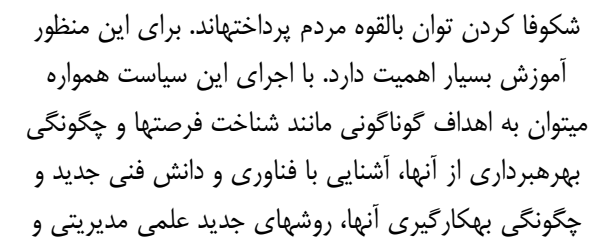 \\
\hline $\begin{array}{c}\mathrm{Z2,Z5,Z7,Z8,Z10,Z11,Z13,Z14,Z15} \\
\text { X1,X2,X3,X4,X5,X6,X7 }\end{array}$ & & 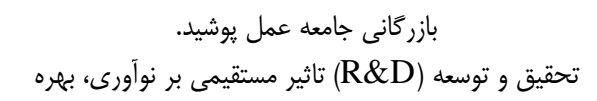 \\
\hline
\end{tabular}




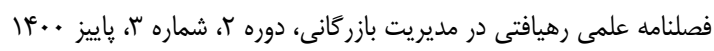

مدير يت ريسك

Z1,Z3,Z4,Z6,Z8,Z9,Z10,Z13,Z14,Z015

$\mathrm{Z} 19, \mathrm{X} 2, \mathrm{X} 4, \mathrm{X} 5, \mathrm{X} 7$
ورى، كيفيت، سطح استاندارد زندگى، سهم بازار و نيز ديخر عواملى كه در افزايش توان رقابتى سازمانها موثر هستند، دارد.

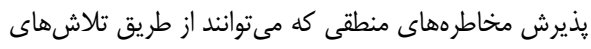

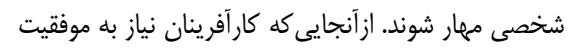

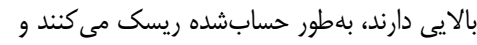
مخاطرههاى معقول را مىيذيرند.
Z2,Z3,Z5,Z6,Z8,Z9,Z11,Z13,Z14,Z15, $\mathrm{Z} 17, \mathrm{X} 1, \mathrm{X} 4, \mathrm{X} 6, \mathrm{X} 7$

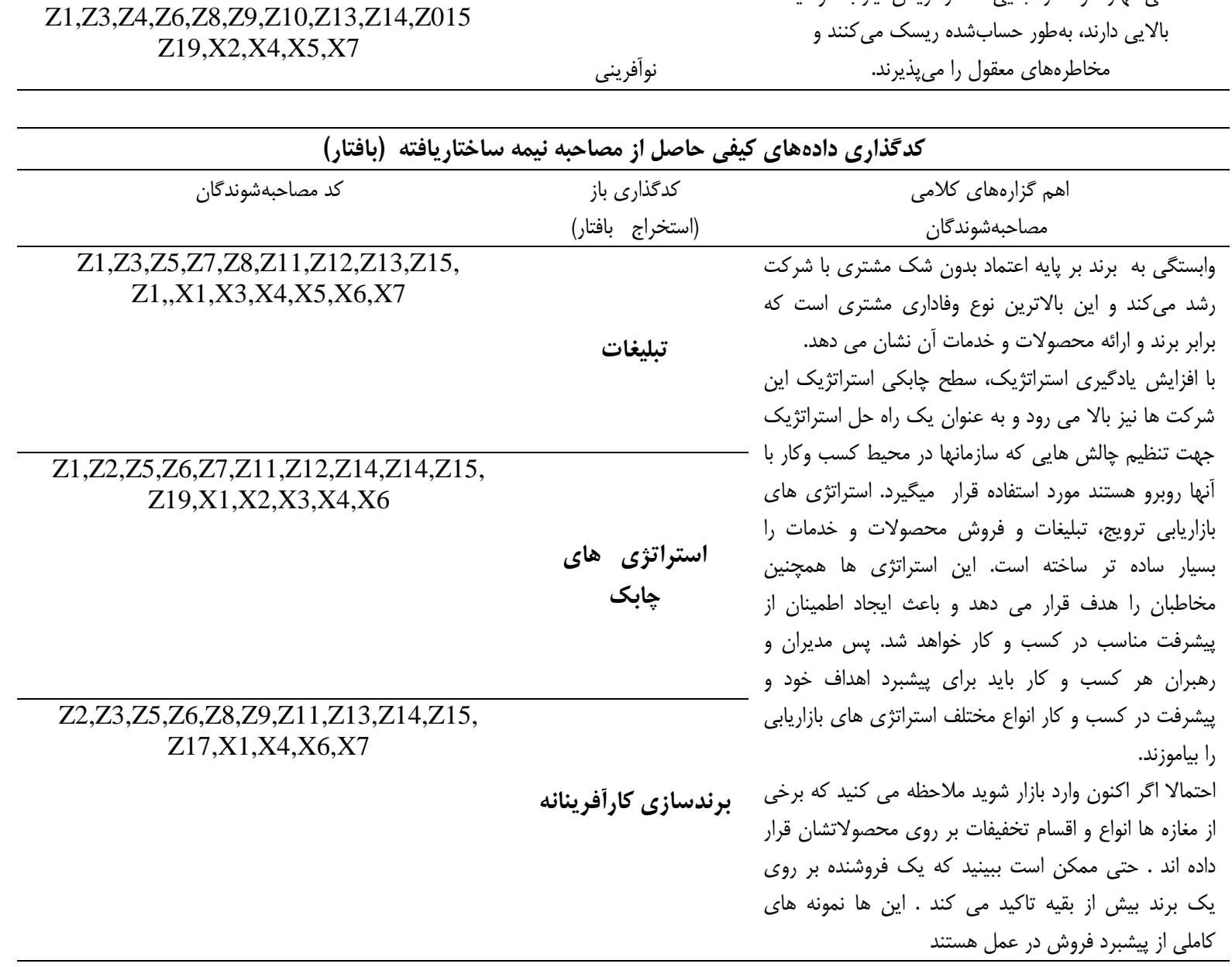

نوآفرينى 


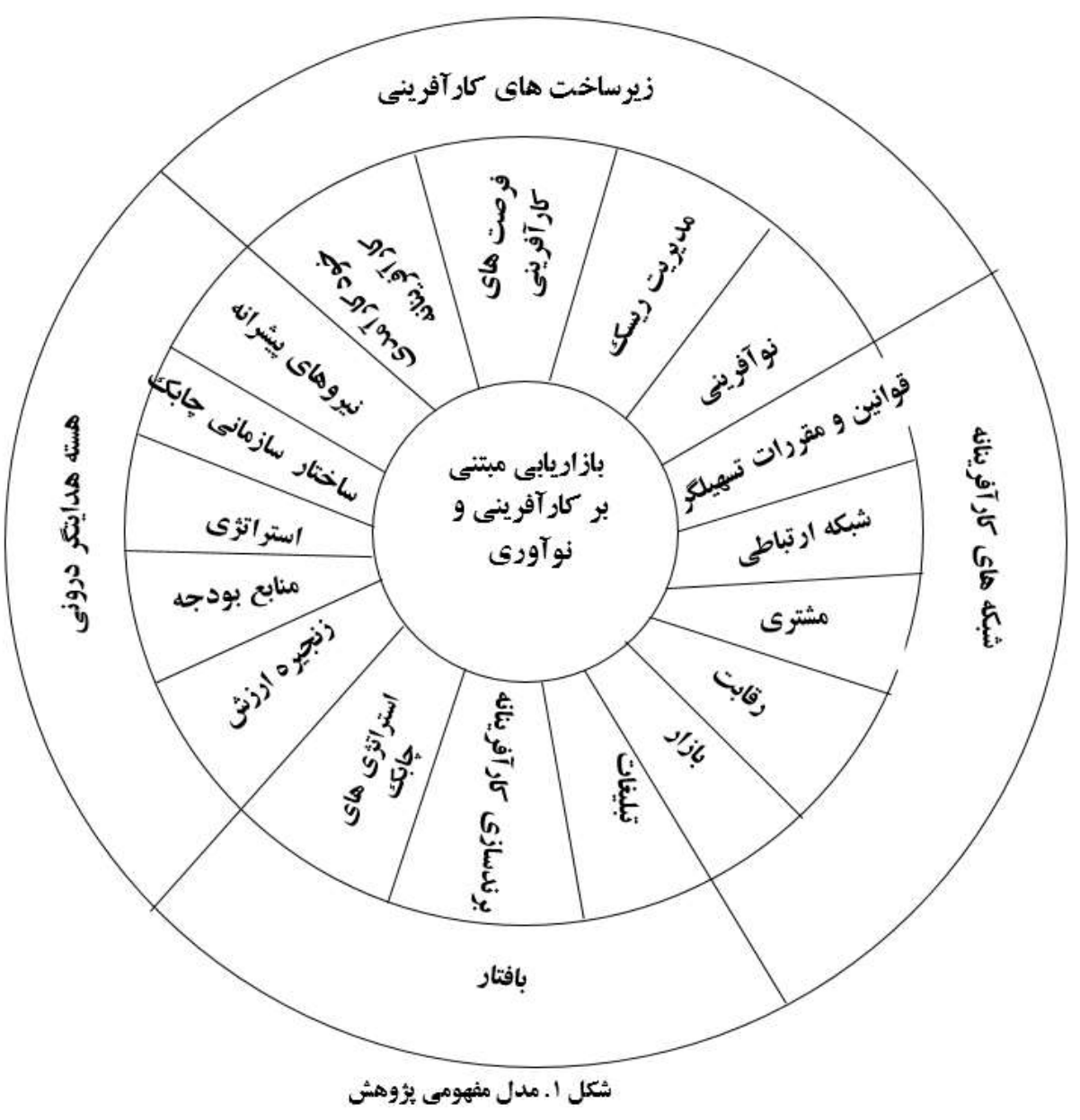

\begin{tabular}{|c|c|c|c|}
\hline مؤلفه & بعد & مفهوم & رديف \\
\hline فرصتهاى كارآفرينانه & زيرساخت كارآفرينى & \multirow{17}{*}{ بازاريابى مبتنى بر كارآفرينى و } & 1 \\
\hline مديريت ريسك & & & \\
\hline خودكار آمدى كارآفرينانه & & & \\
\hline نوأفرينى & & & \\
\hline نيروهاى ييشرانه & هسته هدايتكَ درونى & & r \\
\hline ساختار سازمانى קابك & & & \\
\hline استراتثى & & & \\
\hline منابع بودجه & & & \\
\hline زنجيره ارزش & & & \\
\hline استراتزى هاى حابك & \multirow[t]{3}{*}{ بافتار } & & r \\
\hline برندسازى كارآفرينانه & & & \\
\hline تبليغات & & & \\
\hline قوانين و مقررات تسهيلكَر & \multirow[t]{5}{*}{ شبكههاى كار آفرينانه } & & r \\
\hline شبكه ارتباطى & & & \\
\hline مشترى & & & \\
\hline رقابت & & & \\
\hline بازار & & & \\
\hline
\end{tabular}




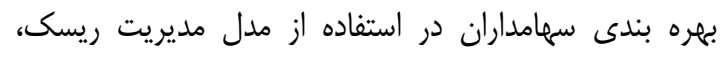

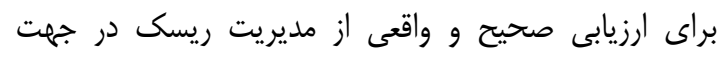

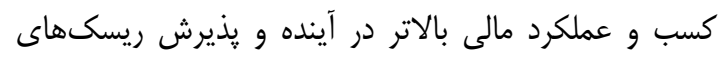

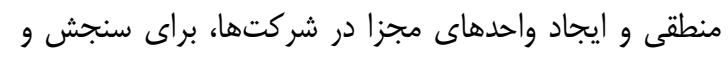

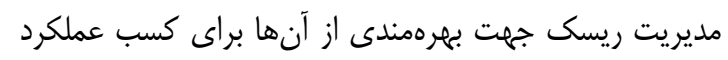

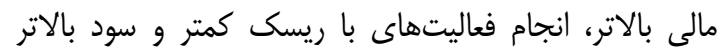

است.

يكى از مؤلفههاى مهم در شركتهاى دانشبنيان توسعه

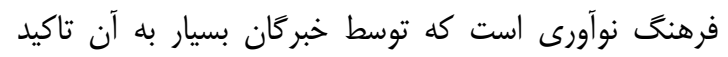

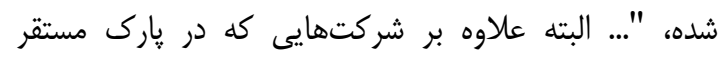

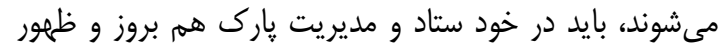

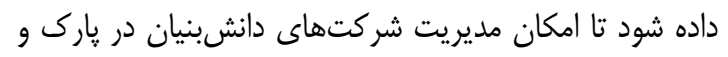

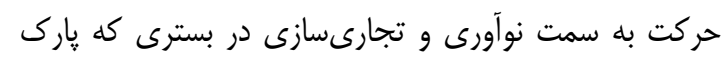

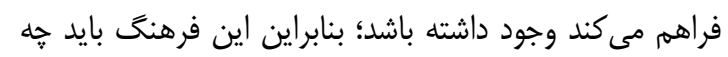

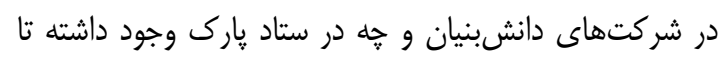

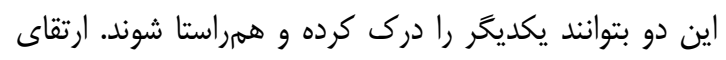

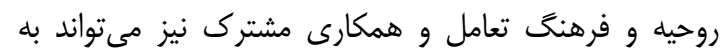

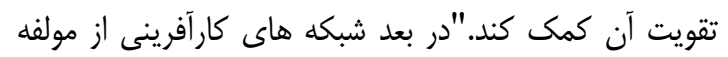

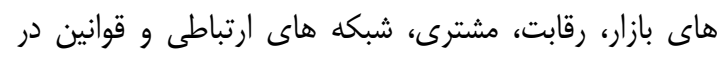

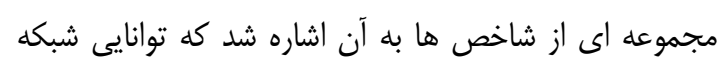

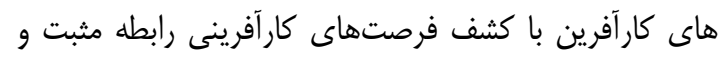

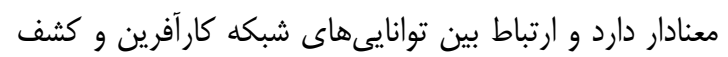

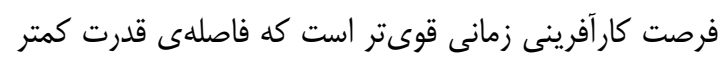

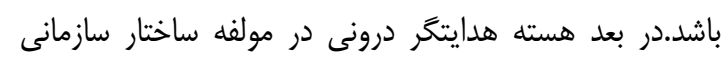

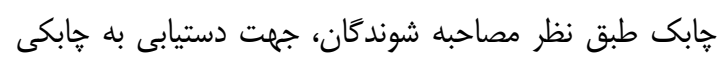

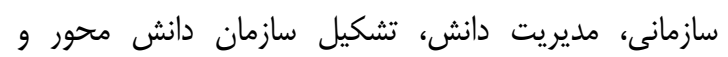
تسهيل جريان ارتباطى و اطلاعاتى در سازمان، جزء كلئ سليدى سانى

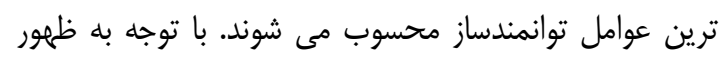

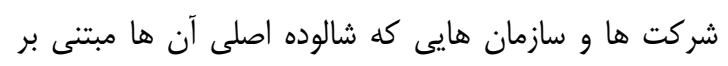

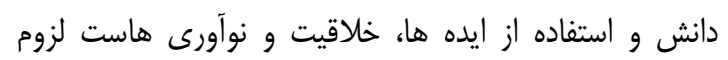

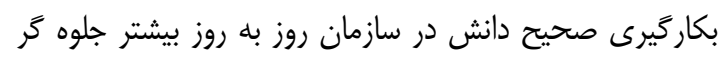

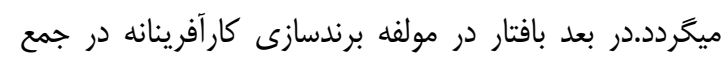

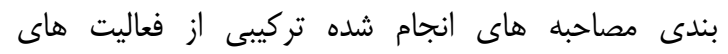

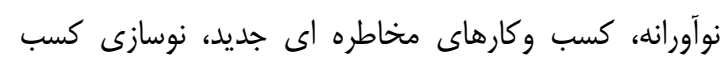

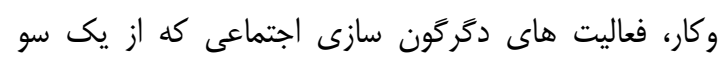

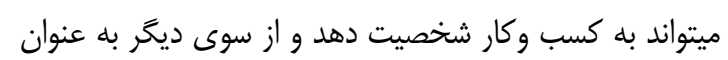
يك عهلد و ييمان عمل كند. بعد شبكه هاى كار آفرينانه. شبكه ارتباطى: برقرارى ارتباطات نزديك با دانشكاهها و و ورئانه

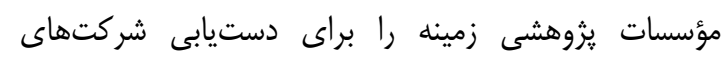

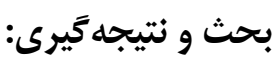

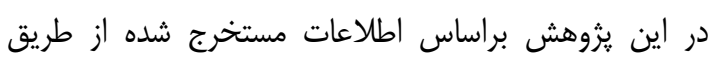

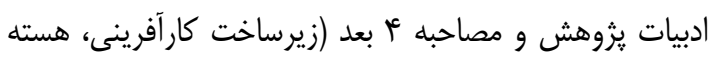

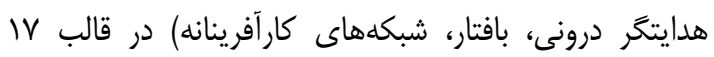

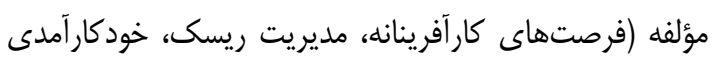

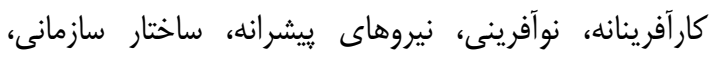

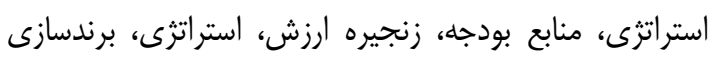

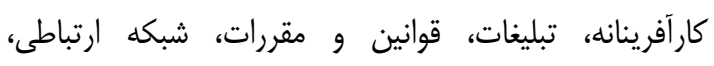

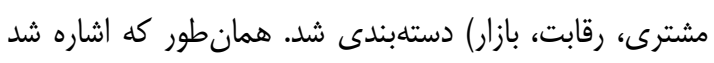

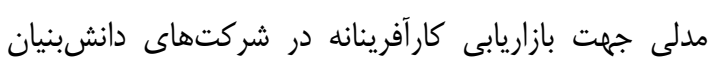

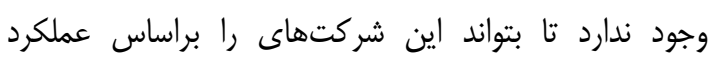

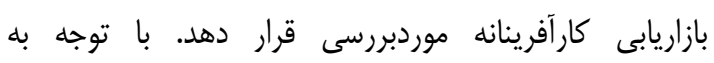

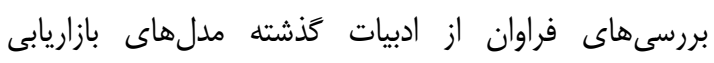

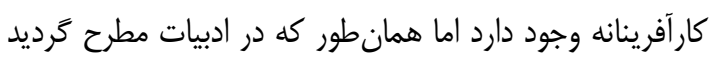

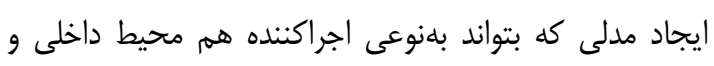

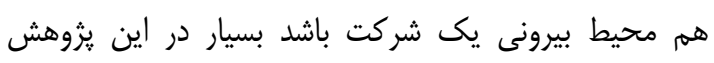
اهميت دارد بهخصوص در شر كتهاى دانشبنينيان.

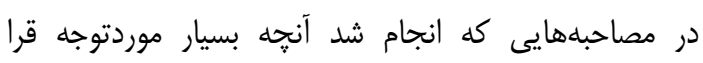

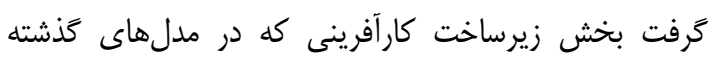

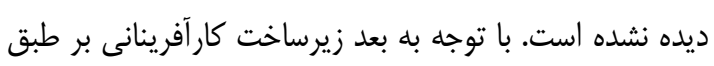

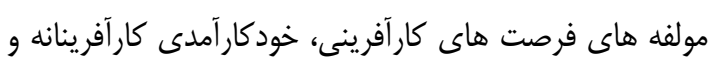

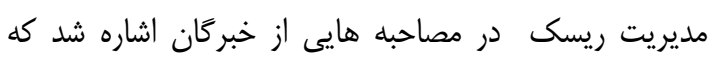

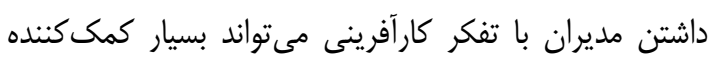

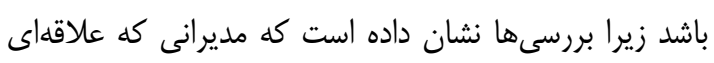

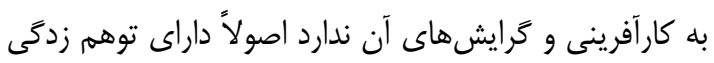

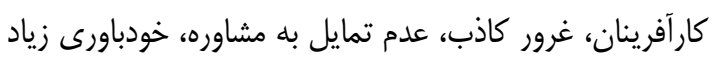

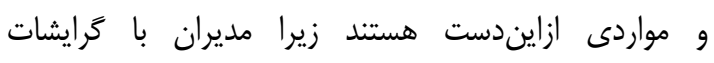

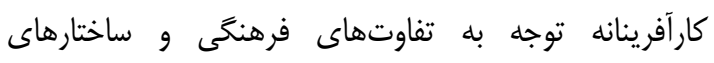

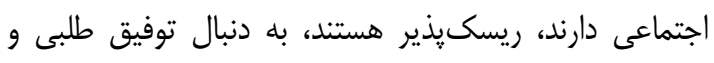

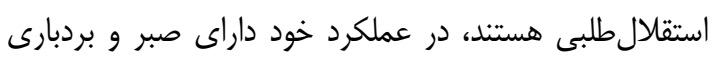

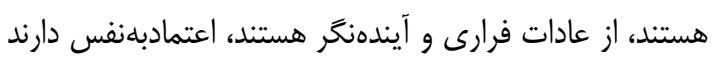

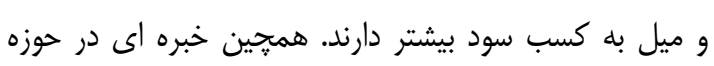

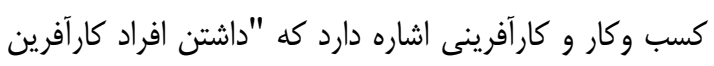

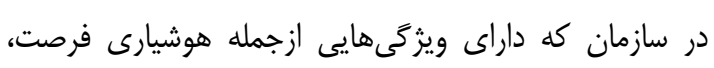

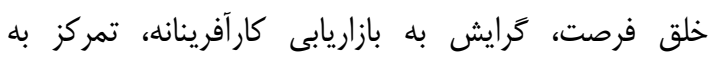

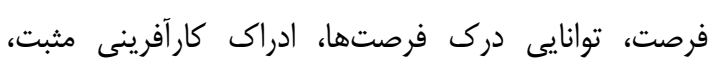

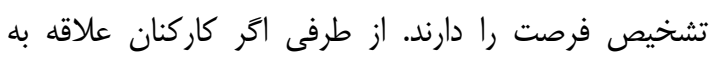

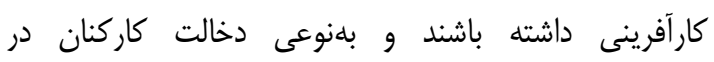

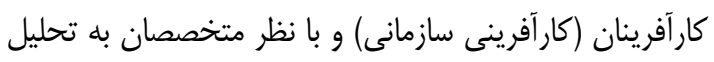
فرصت به ببردازند مىتواند نقش مهم در سازمان ائفان ايفا كند." 


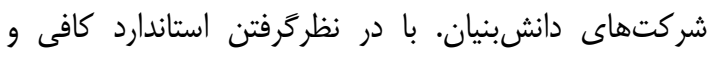

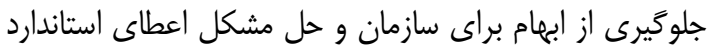

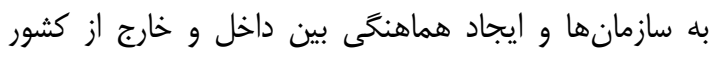

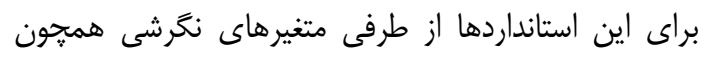

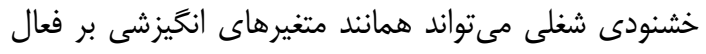

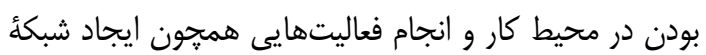

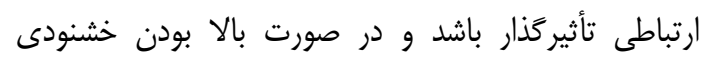

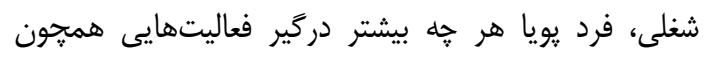
ايجاد شبكأ ارتباطى از طريق جستجوى اطلاعات باشد.

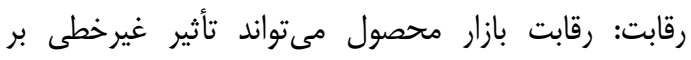

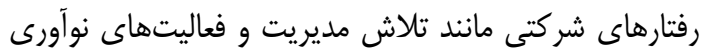

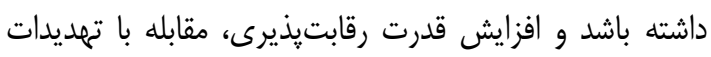

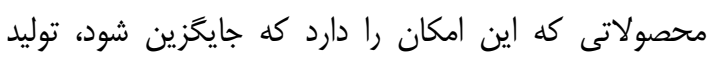

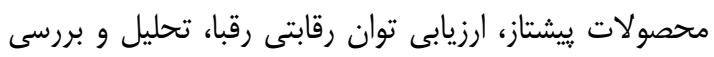

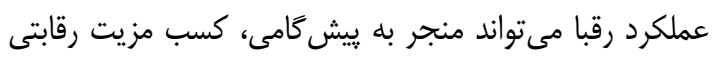

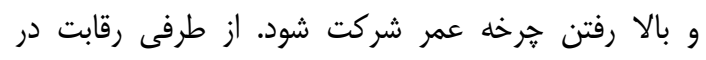

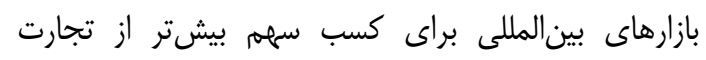

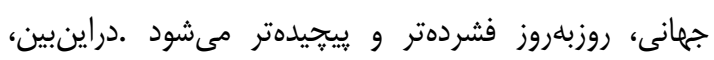

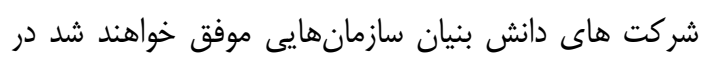

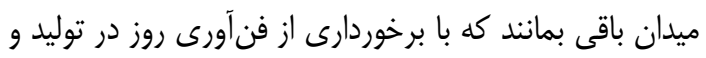

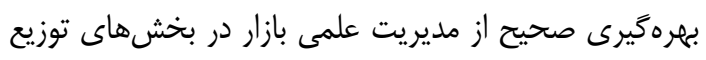

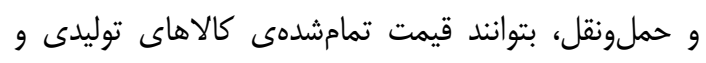
هزينههاى تجارى را براى عرضلى محصولات بتون استاندارد،

كاهش دهند. - مزئه

\section{بعد زير ساخت كار آفرينى:}

شاخص هاى خودكارآمدى كارآفرينانه نيز در كزارئ نارش هاى

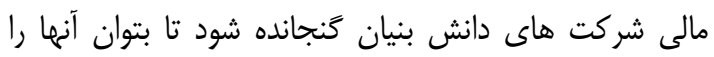

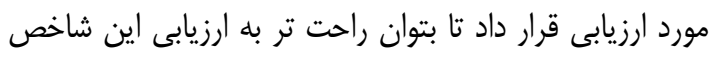

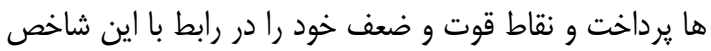

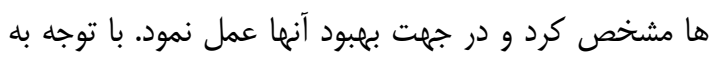

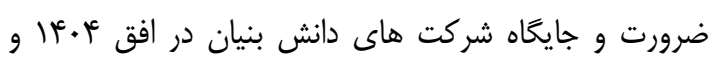

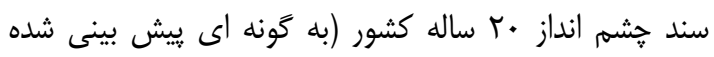

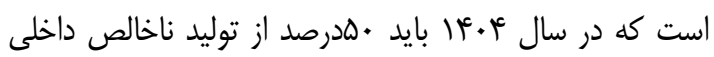

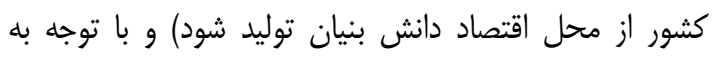

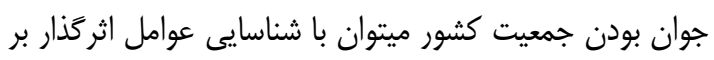

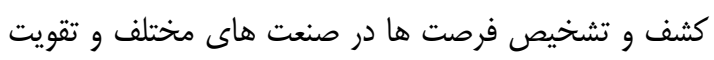

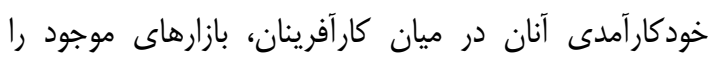

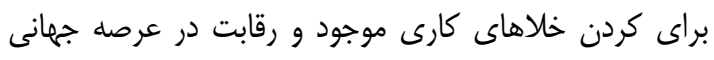

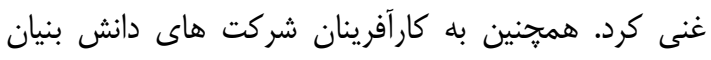

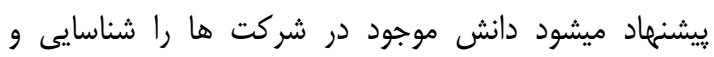

دانشبنيان به دانش و توانمندىهاى نوآورانه كه مبتنى بر

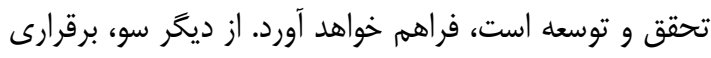

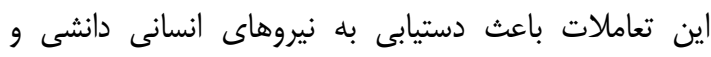
باتجربه شده كه در صنعت و دانشكاهها حضور دارند و بانيه

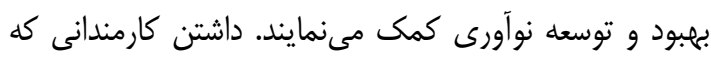

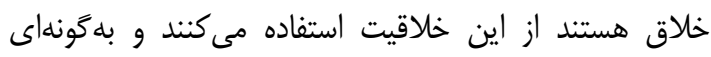

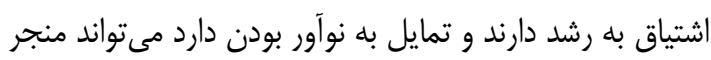

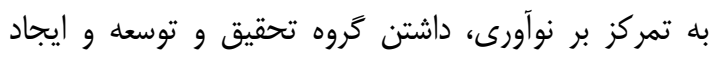

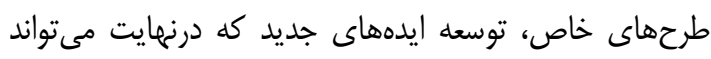

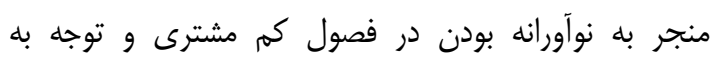

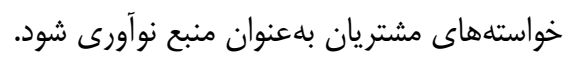

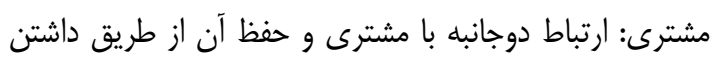

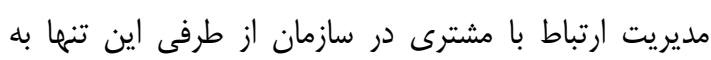

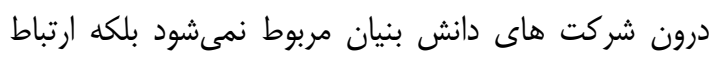

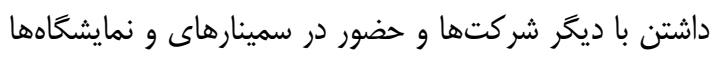

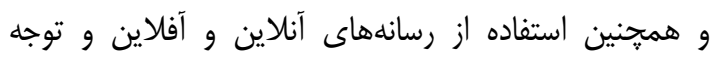
داشتن و ارزش كذاشتن به مشترى مى تواند منجر به انه صميمت الناين

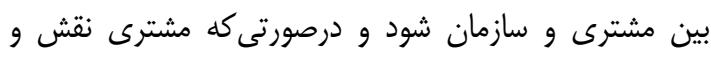

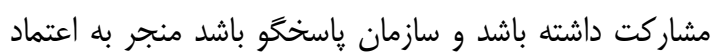
و اشتياق رضايت مشترى مىشود. شركت هاى دان دانش بنان بنيان

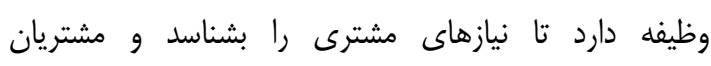

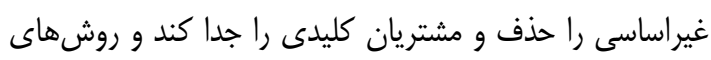

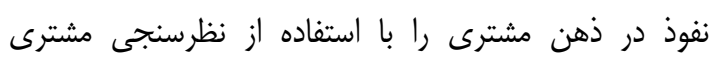

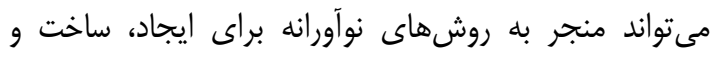

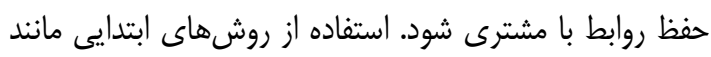

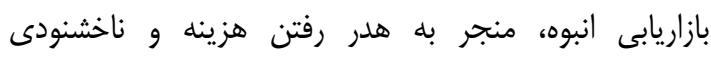

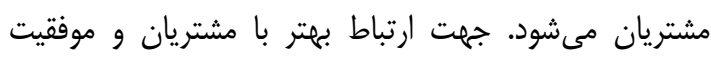

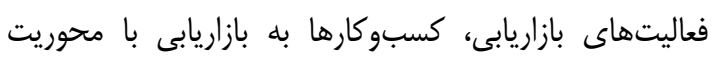

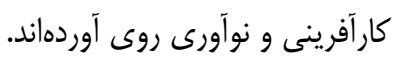

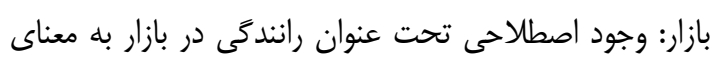

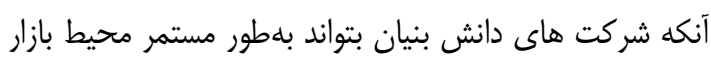

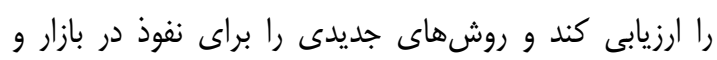

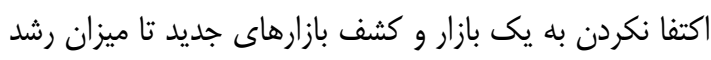

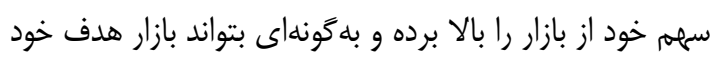

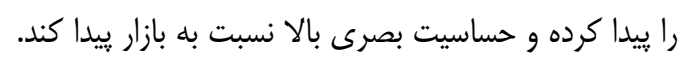

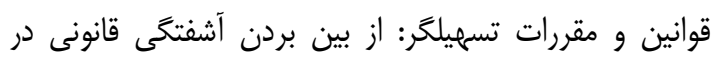

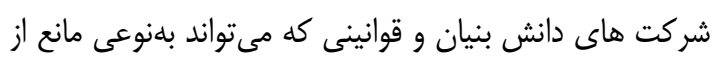

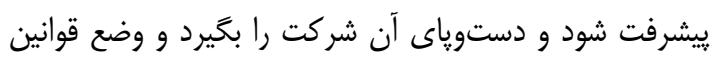

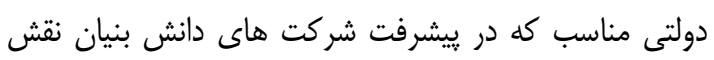

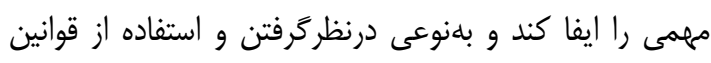


وفادارى به برند تأثير كذار مىباشد و در نظر كرفتن نكرش مصرفكننده نسبت به برند و بهكَّونهاى اعتقاد داشتن به به برند

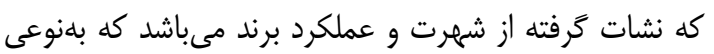

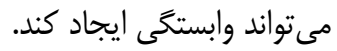

\section{استر انزى هاى جابك:}

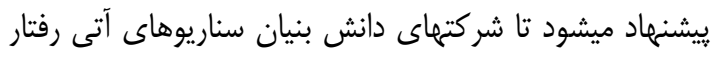
رقبا و محيط را به منظور ارتقا خابكى خود ترسيهم و تمرين

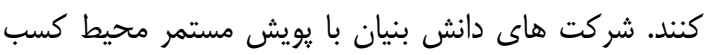
وكار به منظور خلق دانش جديد براى توسعه يادئيرى

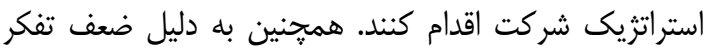

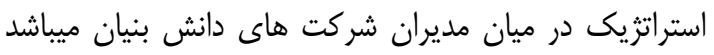

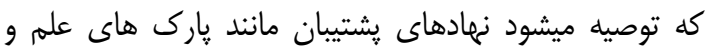

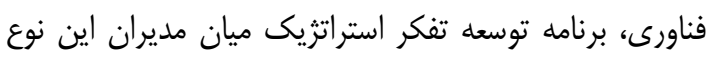

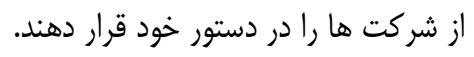

\section{بعد هسته هدايتخً درونى:}

مهرترين موضوع در نيروهاى ييشرانه بحث دانش است داست

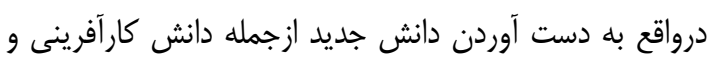

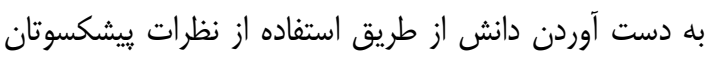

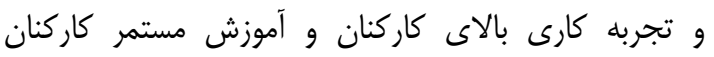

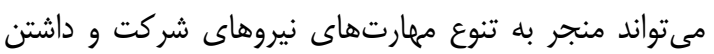

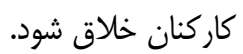

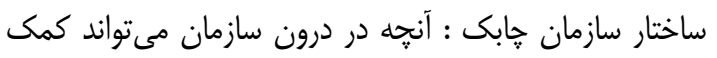

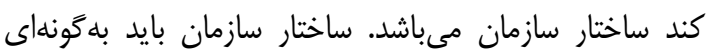

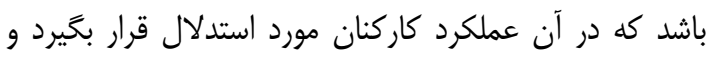
بهبود مستمر عملكرد اتفاق بيفتند، نوع رهبرى كه در در سازمان إنان

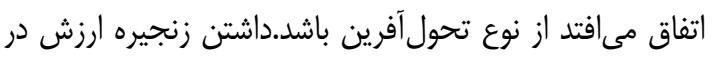

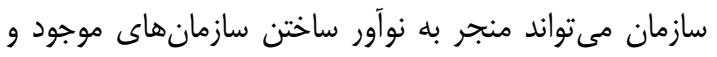

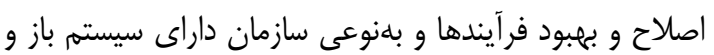

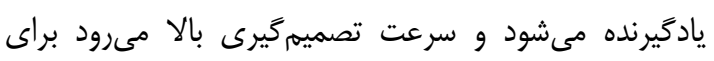

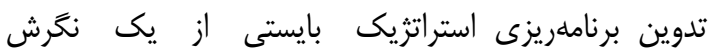

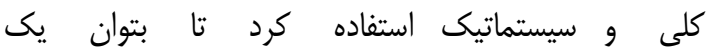

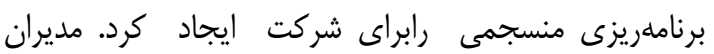

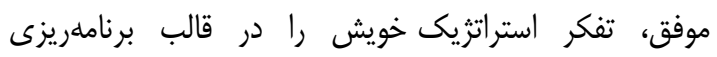

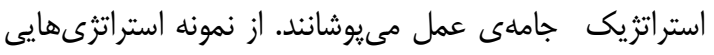

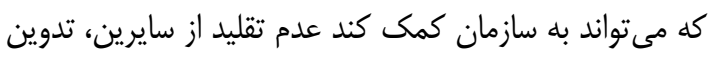

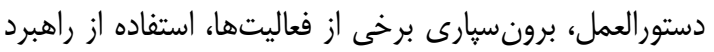

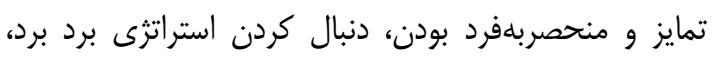
كاهش واسطهها، استراتزىهاى توليد رابطهى ميان سازمى دئى

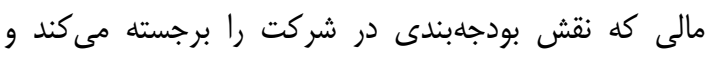

سازماندهى كنند و به منظور قابليت دستيابى و استرخاج بهتر بايد با ايجاد زمينه كسترش تعاملات انسانى و روابط بين

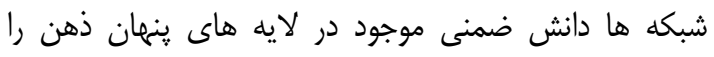

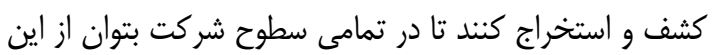
دانش استفاده كرد. با توجه به اينكه در بين ريسك هاى حانى حوزه منابع انسانى بيشترى تاثير را ريسك هاى شكاف هاى مهارتى دارد يِيشنهاد

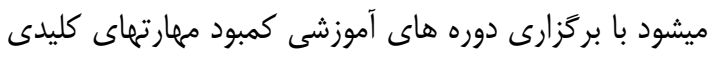

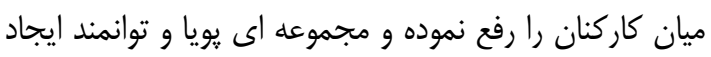

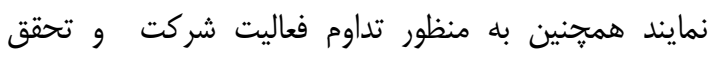
اهداف استراتزيك خصوصا در شركت هاى دانش بندين بنيان،

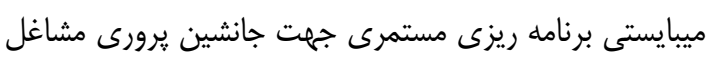

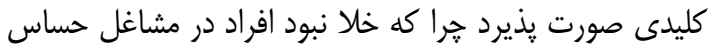

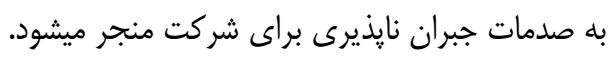

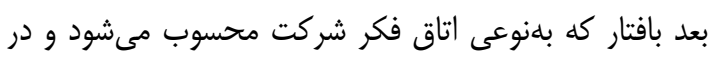

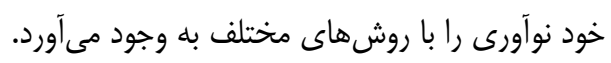

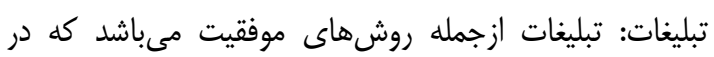

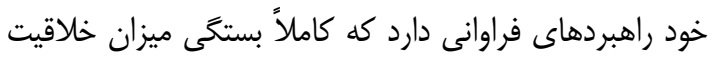

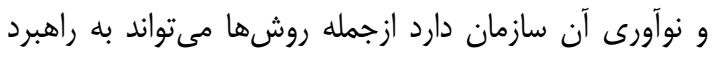

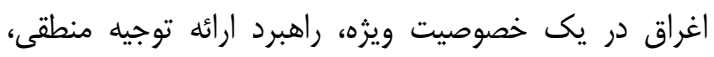

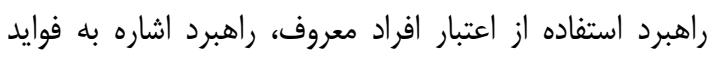

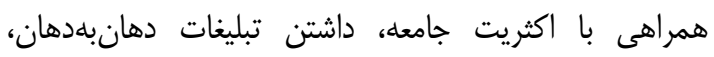

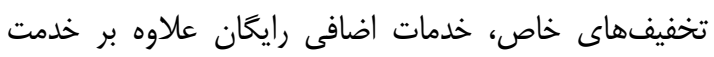

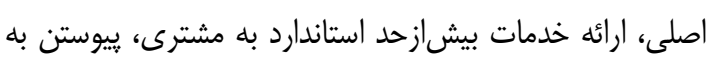
كمبين هاى تبليغاتى.

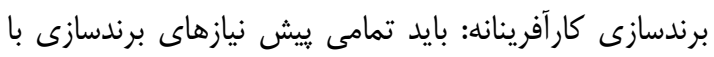

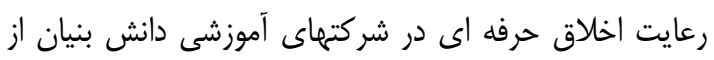

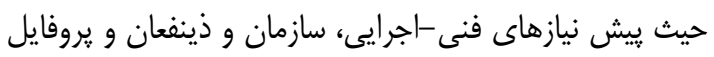

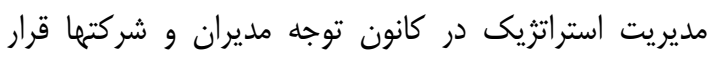

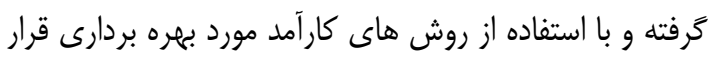

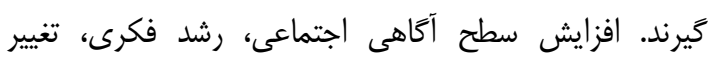

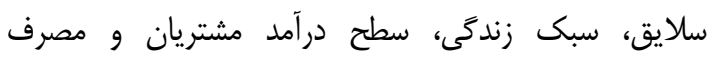

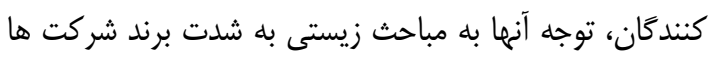

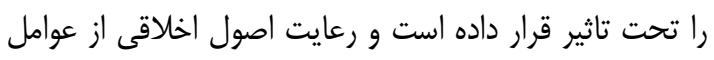

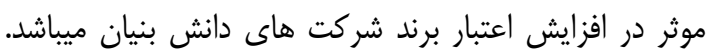

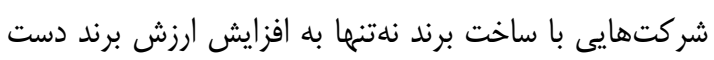

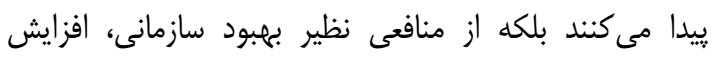

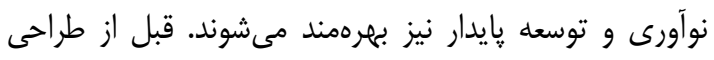

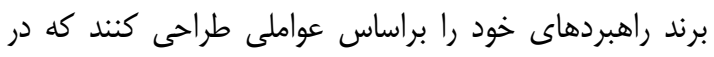

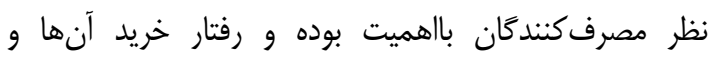




\section{آزادارمكى ،داودى و عليزاده مجد:طراحى الكوى بازاريابى مبتنى بر كار آفرينى و نو آورى در شر كتهاى دانشبنيان}

شعبانى،شيوا(عوس (). كارآفرينى: تغييرى عظيم در كسب و كار، انتشارات دانشخاه كارآفرين،تهران

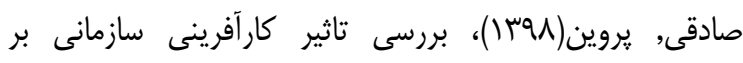
آميخته هاى بازاريابى كارآفرينانه(مورد مطالعه: شركتهاى

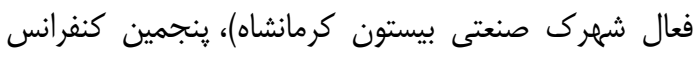

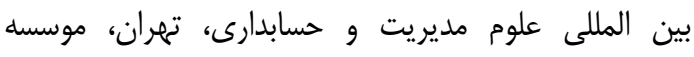

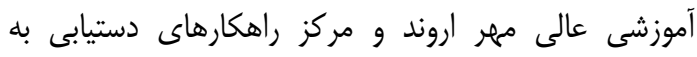
توسعه קيايدار.

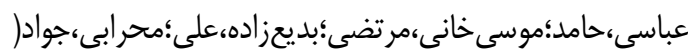

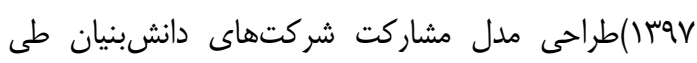

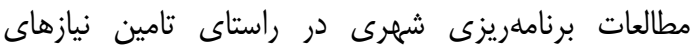

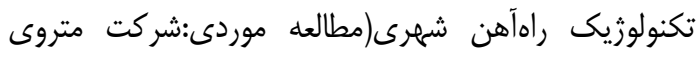

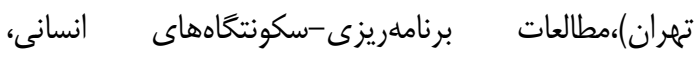

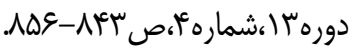

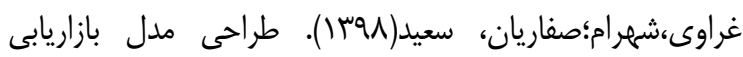

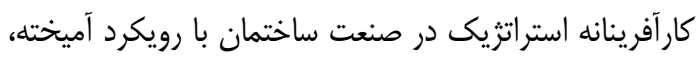

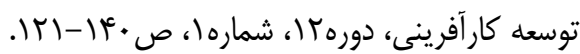

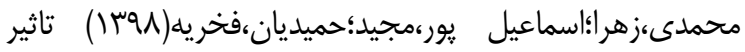

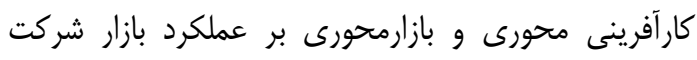

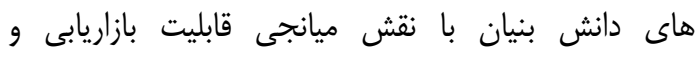

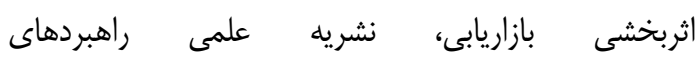

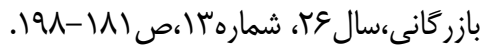

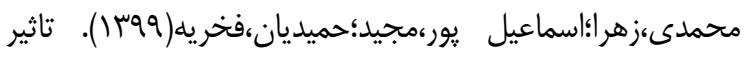

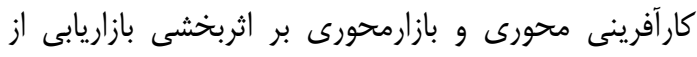

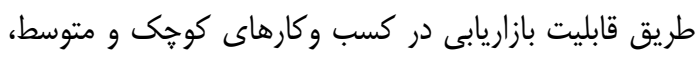

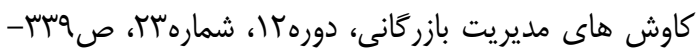

ret

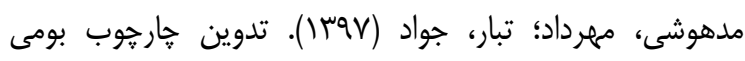

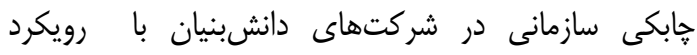

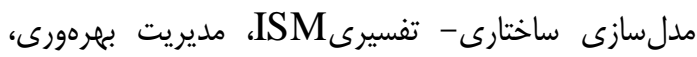

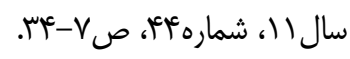

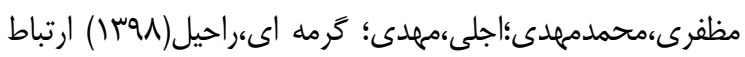

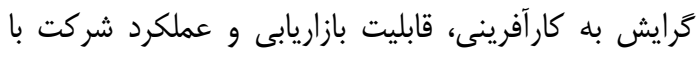

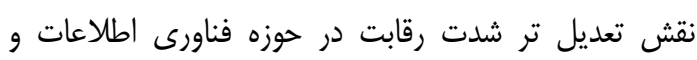

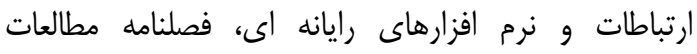

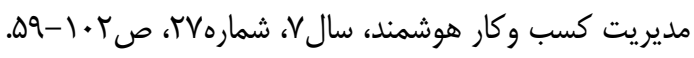

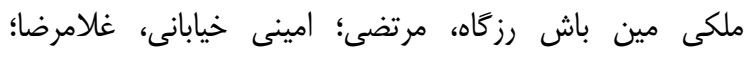

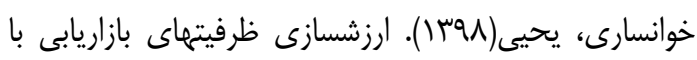

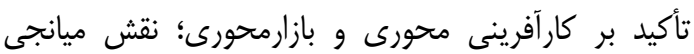

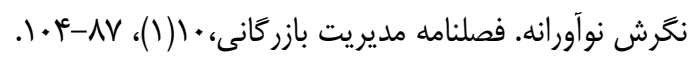

سوددهى، نكتهاى ظريف و نشاندهندهى ضعف در استفاده از آن بهعنوان وسيلهاى مؤثر در هدف كذارى و ارزيابى عملكرد

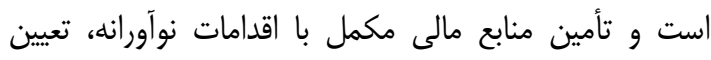
بودجه در هر سال، استفاده از روشهاى ييشيبي مينى بودجه،

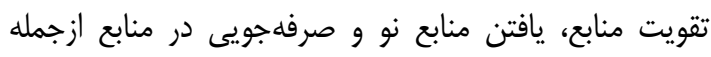

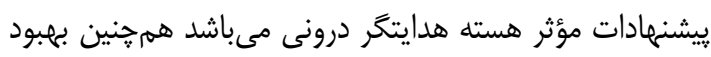

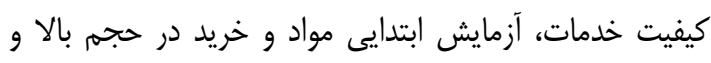

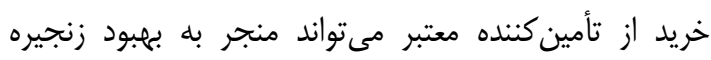

$$
\text { ارزش شود. }
$$

با توجه به نتايج يُوهش حاضر بايد به شركتهاى دان دانشبنيان

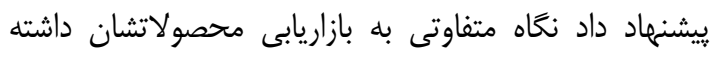

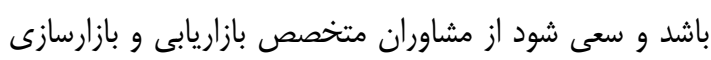

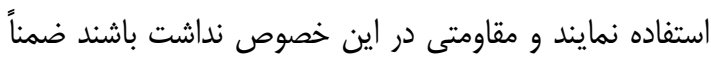

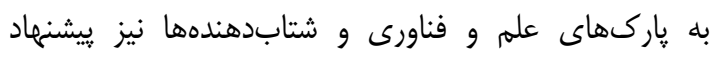
مى كردد تيم مشاورهاى متخصص در علوم انسائ انسانى ازجمله

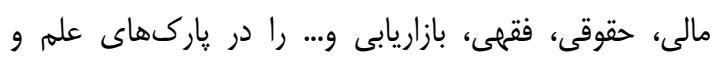

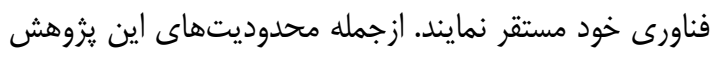

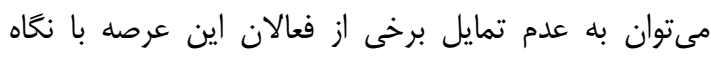
ترس از دست دادن ايده يا نوآورى عنوان نمود.

\section{منابع: (ح)}

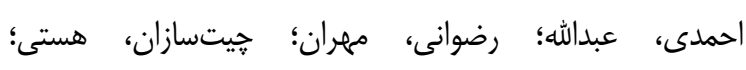

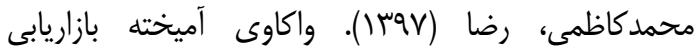

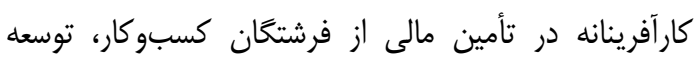

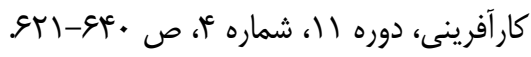

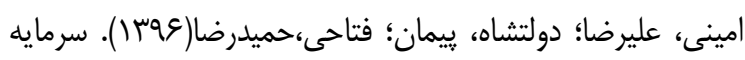

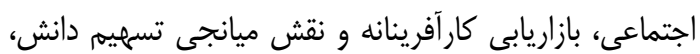

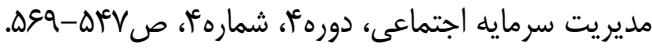

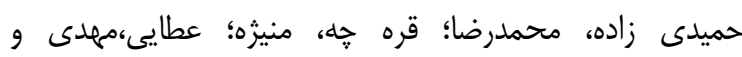

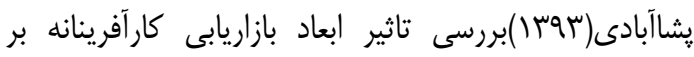

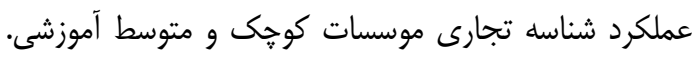

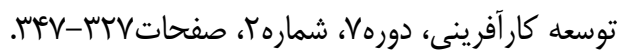
سيف،ياسر:محمدزمانى،محمدرض، دوراك،

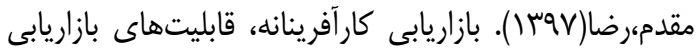

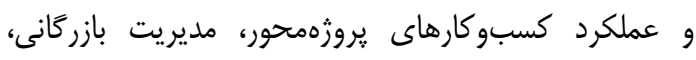

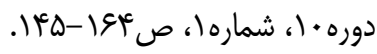

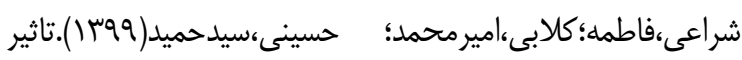

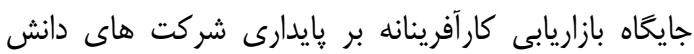

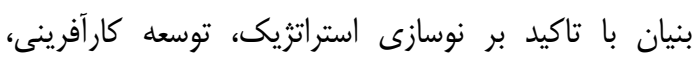

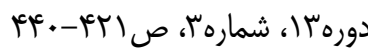


Lekmat, L., Selvarajah, C. and Hewege, C. (2018), "Relationship between market orientation, entrepreneurial orientation, and firm performance in Thai SMEs: the mediating role of marketing capabilities laddawan”, Dogus Üniversitesi Dergisi, doi: 10.31671/dogus.2018.27.

Lotfi , Maryam , Akram Yousefi 2 and Soheil Jafari(2018). The Effect of Emerging Green Market on Greenv Entrepreneurship and Sustainable Development in Knowledge-Based Companies, Sustainability 2018, 10, 2308; doi:10.3390/su10072308

Mathias, B. D., \& Williams, D. W. (2018). Giving up the hats? Entrepreneurs' role transitions and venture growth. Journal of Business Venturing, 33(3), 261-277.

Peterson.M(2018). Modeling country entrepreneurial activity to inform entrepreneurialmarketing research, Journal of Business Research

Sadiku-Dushi Nora, Léo-Paul Dana, Veland Ramadani(2019).

Entrepreneurial marketing dimensions and SMEs performance, Journal of Business Research,100pp:86-99.

Santos,Ismael Luiz dos \& Marinho, Sidnei Vieira (2018) ,Relationship between entrepreneurial orientation, marketing capability and business performance in retail supermarkets in Santa Catarina (Brazil), Innovation \& Management Review,ISSN: 2515-8961

Suleimankadievaa,A.E, V.I. Pilipenkoa, J. Sági(2019). Knowledge Company: Approaches to Assessing New Knowledge and Representation it to Society, Procedia Computer Science 150 (2019) 730-736

Yang, M. (2018). International entrepreneurial marketing strategies of MNCs: Bricolage as practiced by marketing managers, International Business Review, 27(5): 1045-1056.

Zamkova, Nataliia Valerii Bondarenko, Galyna Pchelianska, Oksana Artyukh and Tetyana Murenko,(2020) Implementation of Marketing Audit into

$$
\begin{aligned}
& \text { موسوى نياركى, سيده افسانه؛ امير خانلرى و حميدرضا معصومى، }
\end{aligned}
$$

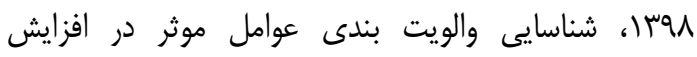

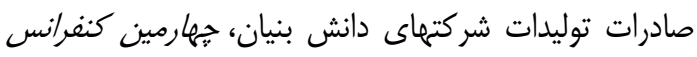

$$
\begin{aligned}
& \text { ملى توانمندسازى جامعه در حوزه علوم انسانى و مطالعات }
\end{aligned}
$$

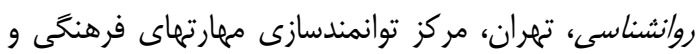

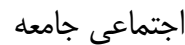

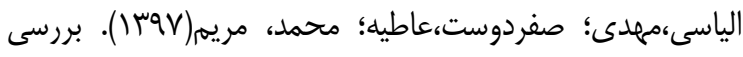

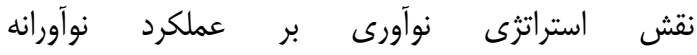

$$
\begin{aligned}
& \text { سازمانها(موردمطالعه: شركتهاى دانشبنيان حوزه زيست }
\end{aligned}
$$

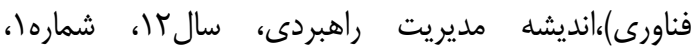

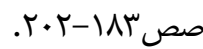

Bocconcelli, R., Cioppi, M., Fortezza, F., Francioni, B., Pagano, A., Savelli, E. and Splendiani, S. (2018), "SMEs and marketing: a systematic literature review", International Journal of Management Reviews, Vol. 20 No. 2, pp. 227-254, doi: 10.1111/ijmr.12128.

Chase J. Edwardsa, Joshua S. Bendicksonb, Brent L. Bakerc, Shelby J. Solomond(2020). Entrepreneurship within the history of marketing, Journal of Business Research

Ghezali,Fatima;Boudi,Adbessamad(2020). The moderating effect of information technology capabilities on the relationship between marketing mix and corporate entrepreneurship, PSU Research Review Vol. 5 No. 2,pp. 101119.

Hidalgo, A. \& D’Alvano, L. (2014). Service innovation: inward and outward related activities and cooperation mode. Journal of Business Research, 67(5), $698-703$.

Jenson, Ian, Richard Doyleb, Morgan P. Miles(2019). An entrepreneurial marketing process perspective of the role of intermediaries in producing innovation outcomes, Journal of Business Research

Jones, B. R. (2010). Entrepreneurial marketing and the web 2.0 interface, Journal of Research in Marketing and Entrepreneurship, 12(2): 143- 152. 
آزادارمكى ،داودى و عليزاده مجل:طراحى الكوى بازاريابى مبتنى بر كار آفرينى و نو آورى در شركتهاى دانشبنيان

the Sphere of Electronic

Entrepreneurship, International Journal of Management, 11(6), pp. 1773-1780 